\title{
Early spring post-fire snow albedo dynamics in high latitude boreal forests using Landsat-8 OLI data
}

Zhuosen Wang ${ }^{\mathrm{a}, \mathrm{b}, \mathrm{c}^{*}}$, Angela M. Erb ${ }^{\mathrm{b} *}$, Crystal B. Schaaf ${ }^{\mathrm{b}}$, Qingsong Sun ${ }^{\mathrm{b}}$, Yan Liu ${ }^{\mathrm{b}}$, Yun Yang ${ }^{\mathrm{d}}$, Yanmin Shuai ${ }^{\text {b }}$ Kimberly A. Casey ${ }^{\text {a,e }}$, Miguel O. Román ${ }^{\text {a }}$

${ }^{a}$ NASA Goddard Space Flight Center, Greenbelt, MD, USA

${ }^{\mathrm{b}} \mathrm{School}$ for the Environment, University of Massachusetts Boston, Boston, MA, USA

${ }^{c}$ NASA Postdoctoral Program Fellow, Goddard Space Flight Center, Greenbelt, MD, USA

${ }^{\mathrm{d}}$ United States Department of Agriculture, Agricultural Research Service, MD, USA

${ }^{\mathrm{e}}$ Earth System Science Interdisciplinary Center, University of Maryland, College Park, MD, USA

*Corresponding Authors: Zhuosen Wang (zhuosen.wang@nasa.gov)

Angela M. Erb (Angela.Erb001@umb.edu)

\begin{abstract}
Taking advantage of the improved radiometric resolution of Landsat-8 OLI which, unlike previous Landsat sensors, does not saturate over snow, the progress of fire recovery progress at the landscape scale $(<100 \mathrm{~m})$ is examined. High quality Landsat-8 albedo retrievals can now capture the true reflective and layered character of snow cover over a full range of land surface conditions and vegetation densities. This new capability particularly improves the assessment of post-fire vegetation dynamics across low- to high- burn severity gradients in Arctic and boreal regions in the early spring, when the albedos during recovery show the greatest variation. We use
\end{abstract}


$30 \mathrm{~m}$ resolution Landsat-8 surface reflectances with concurrent coarser resolution $(500 \mathrm{~m})$

MODIS high quality full inversion surface Bidirectional Reflectance Distribution Functions (BRDF) products to produce higher resolution values of surface albedo. The high resolution full expression shortwave blue sky albedo product performs well with an overall RMSE of 0.0267 between tower and satellite measures under both snow-free and snow-covered conditions. While the importance of post-fire albedo recovery can be discerned from the MODIS albedo product at regional and global scales, our study addresses the particular importance of early spring post-fire albedo recovery at the landscape scale by considering the significant spatial heterogeneity of burn severity, and the impact of snow on the early spring albedo of various vegetation recovery types. We found that variations in early spring albedo within a single MODIS gridded pixel can be larger than 0.6. Since the frequency and severity of wildfires in Arctic and boreal systems is expected to increase in the coming decades, the dynamics of albedo in response to these rapid surface changes will increasingly impact the energy balance and contribute to other climate processes and physical feedback mechanisms. Surface radiation products derived from Landsat-8 data will thus play an important role in characterizing the carbon cycle and ecosystem processes of high latitude systems.

Key words: Landsat- 8 snow albedo, post-fire recovery, albedo heterogeneity and dynamics

\section{Introduction}

In North American boreal forests, the total burned area and frequency of large, naturally ignited fires has increased dramatically over the past four decades (Kasischke \& Turetsky, 2006). Studies have shown that rapidly increasing surface temperatures in Arctic and boreal regions 
(Hinzman et al., 2005) may both lengthen the fire season and cause shifts in the fire regime (Flannigan et al., 2005; Gillett et al., 2004; Kasischke \& Turetsky, 2006; Westerling et al., 2006). As a primary disturbance agent, fire alters vegetation dynamics, including vegetation structure and composition (Goetz et al., 2012; McGuire et al., 2004; Viereck, 1973; Foote, 1983), surface energy balance (Amiro et al., 2006; Chambers \& Chapin, 2002; Liu et al., 2005; Lyons et al., 2008; Randerson et al., 2006; Rocha \& Shaver, 2011), and carbon cycling (Balshi et al., 2007; Balshi et al., 2009; Bond-Lamberty et al., 2007; Turetsky et al., 2011). Furthermore, fire strongly influences the climate through initial aerosol and gas emissions and subsequent surface albedo feedbacks (Bowman et al., 2009; Flanner et al., 2011; McGuire et al., 2006; Randerson et al., 2006). The complex factors influencing vegetation recovery and the long term effects of fire on radiative forcing and climate are not yet fully understood. Some quantitative assessments suggest that albedo changes post-fire, due to increased snow extent, may be significant enough to counter the initial carbon release, and thus fires may not necessarily accelerate climate warming in northern regions (Bala et al., 2007; Brovkin et al., 2004; Randerson et al., 2006). These complex relationships can be better understood by analyzing the albedo dynamics within the burned area in a fire, or fire scar, considering both the spatial distribution and heterogeneity of the fire severity, the vegetation and the multiple factors affecting recovery.

Overall, albedo recovery depends on the size, frequency, and burn severity of the fire. In particular, burn severity, a measure of the degree to which an area is disrupted by fire (NWCG, 2005), has important implications for post-fire ecosystem recovery in boreal forests (Beck et al., 2011; French et al., 2008; Goetz et al., 2007; Johnstone \& Chapin, 2006; Mack et al., 2008). Recent temporal analyses have shown that, in addition to increasing fire area and frequency, high 
latitude fires are also increasing in severity (Duffy et al., 2007; Kasischke \& Turetsky, 2006; Turetsky et al., 2011). The spatial variations in burn intensity and burn severity influence the recruitment and establishment of boreal forest species within the burn perimeter (Epting \& Verbyla, 2005; Johnstone \& Chapin, 2006; Johnstone et al., 2010; Shenoy et al., 2011; Zasada et al., 1983; Zasada et al., 1987). As vegetation cover strongly impacts surface albedo particularly during the early spring snow season, successional post-fire dynamics play a large role in land surface albedo recovery and impact the total fire radiative forcing. As such, understanding the role burn severity plays in forest recovery is key to understanding snow-vegetation heterogeneity and albedo feedbacks. Previous post-fire albedo recovery studies (Beck et al., 2011; Jin et al., 2012a; 2012b; Lyons et al., 2008; Randerson et al., 2006) have indicated that the $500 \mathrm{~m}$ MODIS BRDF/NBAR/albedo product (Schaaf et al., 2002; 2011) captures post-fire albedo trajectories across different burn severity and forest types at regional and global scales. Recent studies have assessed the within fire scar variability in albedo and burn severity classes for Mediterranean vegetation (Veraverbeke et. al., 2012). However, post-fire early spring snow albedo dynamics within the spatial footprint of fire scars and albedo variability within moderate spatial resolution $(500 \mathrm{~m})$ are not yet fully understood.

The goal of this study is to investigate the impact of burn severity and post fire vegetation dynamics on early spring surface albedo at the fire scar level by using the finer spatial resolution (30m) and improved radiometric fidelity (12 bit) of Landsat- 8 data to emphasize the effect of surface heterogeneity on snow albedo across Alaskan boreal forests. The instrumentation improvements of Landsat-8 allow for new assessments of snow albedo heterogeneity and the early spring albedo recovery at the characteristic scale of ecosystem disturbance by fire. Here, 
the algorithm developed by Shuai et al., $(2011 ; 2014)$ and validated for non-snow covers by Román et al., (2013) is used to compute Landsat- 8 snow albedo by combining Landsat- 8 surface reflectance with MODIS BRDF information. We generated Landsat-8 full expression blue sky snow albedo by also considering the surface multi-scattering effect which has been shown to be significant over snow covered surfaces (Román et al., 2010). Huang et al. (2013) attempted to capture fine scale post-fire summer (snow-free) albedo dynamics using a Landsat albedo that assumes a Lambertian surface. In omitting the BRDF shape correction, these surface albedo estimates are either under or overestimated (Lucht \& Lewis, 2000; Román et al., 2011). The real impact of post fire albedo dynamics is governed by the extent of exposed snow cover during the early spring snow season (Liu et al., 2005; Amiro et al., 2006; Lyons et al., 2008; O'Halloran et al., 2014). Snow albedo values also vary with the vegetation stature. Albedo is high in bare areas with low profile vegetation and low over forested regions, since the canopy decreases the illuminated signal from understory snow. The data presented here take full advantage of the increased radiometric resolution of Landsat-8, which does not saturate over snow and provides improved distinction between snow and clouds.

\section{Study area}

Ten burned sites distributed across Alaska's boreal forest region were used in this study (Figure

1, Table 1). The sites were selected based on the availability of early spring, cloud free Landsat- 8 observations and the availability of burn severity information from the Monitoring Trends in Burn Severity (MTBS) datasets (Eidenshink et al., 2007). No return fires were found within these scars during the study period. An initial land cover assessment was done at each site using the National Land Cover Database (NLCD) (http://www.mrlc.gov/index.php). The Landsat 
based NLCD provides land cover at the same spatial resolution (30m) as Landsat albedo data. In general, land cover of Alaska primeval forests is relatively stable before a major disturbance event such as fire. As such we assume the pre-fire land covers at sites \#8, \#9 and \#10, burned in 2010, are consistent with the land covers in the 2001 NLCD for Alaska. The dominant pre-fire land cover at the ten selected sites was evergreen forest with some deciduous and mixed forest at sites \#4, \#6, and \#10. Where the fires occurred prior the availability of the 2001 NLCD, pre-fire surface conditions were determined by the surrounding unburned forest class. At site \#1, the surrounding unburned land types in the northern portion of the fire scar were woody wetlands and emergent herbaceous wetlands. Therefore, only the forested areas to the south of this site were used to assign the appropriate pre-fire land type during the study period (Figure 2). In summary, these ten sites were burned from 1984 to 2010 at roughly five year increments. The burned area of these sites ranged from 25.64 to $744.71 \mathrm{~km}^{2}$.

\section{Datasets}

\subsection{Landsat datasets}

The Operational Land Imager (OLI) onboard Landsat-8 was launched in February, 2013 continuing the heritage of Landsat-7 ETM+. However, Landsat-8 provides greatly improved signal-to-noise (SNR) radiometric performance (Roy et al., 2014) which allows the capture of reflectance information over snow-covered surfaces without sensor saturation. This new development is crucial in understanding post-fire recovery as snow dynamics play a large role in determining the albedo of high latitude burned regions. The atmospherically corrected hemispherical directional surface reflectance for Landsat-8 can now be ordered directly from the U.S. Geological Survey (USGS) Earth Resources Observation and Science (EROS) Center 
Science Processing Architecture (ESPA) (http://espa.cr.usgs.gov). This Landsat-8 surface reflectance uses the specialized L8SR software which calibrates and atmospherically corrects top of atmosphere inputs (Masek et al., 2006; Schmidt et al., 2013). Surface reflectance is not generated for scenes with a solar zenith angle of greater than 76 degrees, and we further restricted the solar angle to 70 degrees to guarantee high quality data from both the Landsat- 8 and MODIS sensors (Wang et al., 2012). The cloud, cloud shadow, snow, and water in each image is flagged using the newly integrated Function of mask (Fmask) cloud and cloud shadow detection algorithm (Zhu \& Woodcock, 2012; Zhu et al., 2015), which combines the object based cloud and cloud shadow matching algorithm developed for Landsat-5 and Landsat-7 with the enhanced cirrus cloud detection capabilities provided by the new Landsat- 8 shortwave infrared (SWIR or cirrus) band (Band nine, 1.36-1.38 $\mu \mathrm{m}$ ). The cirrus cloud detection algorithm is based on thresholding of the SWIR band such that bright values greater than 0.2 are classified as high latitude clouds based in the strong water absorption at this wavelength and the small above cloud two way water vapor path lengths (Gao et al.,1993).

\subsection{Burn severity data}

The burn severity datasets were compiled by the Monitoring Trends in Burn Severity (MTBS) project (Eidenshink et al., 2007) (Figure 2). The MTBS project identifies and characterizes large fire events (>404 hectares) in the continental United States, Alaska, and Hawaii. The project uses Landsat imagery to identify the burn extent and classify the burn severity into five categories (1 = unburned to low severity, $2=$ low severity, $3=$ moderate severity, $4=$ high severity, and $5=$ increased greenness). The severity is assessed using the Difference Normalized Burn Ratio (dNBR) which considers the Normalized Burn Ratio in pre and post fire imagery (Epting et al., 
2005; García \& Caselles, 1991; Key and Benson, 2006). The intra-annual variability of dynamic vegetation can have a strong effect on dNBR values (Lhermitte et. al .2011; Veraverbeke et. al. 2011). The ten sites highlighted in this study are dominated by evergreen forests which tend to have small intra-annual variability. High dNBR values are linked to increased burn severity as they represent a decrease in the photosynthetic activity (decrease in the near infrared) and an increase in the reflectance of Landsat Band seven (2.09-2.35 $\mu \mathrm{m}$ for ETM+), indicating an increase in ash, carbon, and/or soil, as well as a decrease in surface materials holding water (Lutz, 2011).

\subsection{Land cover data}

The National Land Cover Database (NLCD) products, generated by the Multi-Resolution Land Characteristics (MRLC) Consortium, provide the capability to assess the land cover changes across the United States (http://www.mrlc.gov/index.php). We used both the 2001 and 2011 NLCD (Homer et al., 2007), which are derived from 30m resolution Landsat-5 and Landsat-7 imagery to assess post-fire recovery (Figure 3). The 16-class land cover classification scheme of NLCD is developed through a decision tree algorithm (Vogelmann et al., 1998) and provides a good means for assessing changes in land cover and identifying trends. The overall accuracy of the 2001 Level II classifications over Alaska is 83.9\% (Stehman \& Selkowitz, 2010).

\subsection{Tower-based albedo measurements}

No ground albedo measurements were collected over the burn recovery study areas in this paper. Therefore, validation of the Landsat-8 full expression blue sky surface albedo values was instead performed at six representative tower sites (Figure 4) from the International Baseline Surface 
Radiation Network (BSRN), NOAA's Surface Radiation Budget Network (SURFRAD), the Arctic Observatory Network (AON) and the Ameriflux network (Table 2). These sites represent a range of land covers and locations and were selected for the availability of snow-covered conditions. The Table Mountain SURFRAD site was previously used for the validation of the Landsat-5 and Landsat-7 snow free isotropic blue sky albedo (Shuai et al, 2011). The Table Mountain and Sioux Falls sites are grassland with low profile vegetation. Morgan Monroe State Forest is a mixed hardwood site with 60 - 80 years old secondary growth trees; tulip poplar, white oak, red oak, and sugar maple are the dominant species. The average canopy height at this site is 27 meters, with minor topographical features including small ravines. The Howland west site is an evergreen needleleaf forest in central Maine. The dominant species are red spruce, hemlock and white pine with an average canopy height of 19.5 meters. The Barrow and Imnavait sites are located in Alaska and represent the opportunity to validate the albedo product in high latitude systems where solar zenith angle and illumination conditions present unique challenges (Wang et al, 2012). The vegetation at the Barrow site is unmanaged and undisturbed with dominant species including Carex aquatilis, Dupontia fisheri and Arctophila fulva. The Imnavait tower, located in the Imnavait Creek watershed, is surrounded by undisturbed moist acidic tussock tundra. The tower location, instrumentation tower height and footprint and total number of Landsat-8 images used for validation at each site are listed in Table 2.

At these sites the global upwelling and downwelling solar radiation are continuously recorded with Eppley pyranometers at the Imnavait site and the SURFRAD sites and Kipp and Zonen albedometers at the Howland West Forest, Barrow and Morgan Monroe sites. The actual blue sky albedo is calculated as the ratio of upwelling to downwelling radiation. To correspond with 
the Landsat- 8 imagery, tower data for the date and time of Landsat acquisition were extracted.

The SURFRAD and Barrow sites return values every minute. For these sites, all values within a 20 minute window around the acquisition time were averaged. At the Morgan Monroe, Howland West and Imnavait site, the data are recorded at 30 minute intervals and the time stamp closest to the image acquisition was selected. The reported uncertainties in these irradiance measurements generally ranged from $\pm 2 \%$ to $\pm 5 \%$ for both the upward- and downward-looking pyranometers (Augustine et al., 2000). In addition, rough surfaces and viewing obstructions may increase the uncertainty of measurements (Lhermitte et al., 2014). All available high quality, cloud free Landsat- 8 scenes with corresponding tower data were used in the validation analysis. For the early spring snow albedo validation 28 data points were used ranging from Day of Year (DOY) 004 to 142 and 248 to 345 for the Landsat- 8 data record of 2013-2015. To account for the latitude of the Alaskan sites, all Landsat- 8 scenes with a solar zenith angle of greater than $70^{\circ}$ at the tower location were omitted as the accuracy of the MODIS and Landsat- 8 albedos are reduced above this threshold (Wang et al, 2012). A greater number of snow-free scenes were available with a total to 89 validation points ranging from DOY 015 to 361 .

\subsection{MODIS data}

MODIS V006 daily BRDF/Albedo products (MCD43) (Schaaf et al., 2002, 2011; Shuai et al., 2013; Wang et al., 2012, 2014) are utilized to convert Landsat-8 near nadir reflectance to albedo. The MCD43 products which have been produced since 2000 rely on the semi-empirical kernel linear RossThick-LiSparse Reciprocal (RTLSR) BRDF model to describe the reflectance anisotropy. The snow status of the area of the Landsat- 8 studies area is compared with standard daily MODIS snow product (MOD10A) (Hall et al., 2002). The Aerosol Optical Depth (AOD) 
for the full expression blue sky albedo calculation is collected from MODIS (MOD08) product (Remer et al., 2005).

\section{Methodology}

\subsection{Landsat-8 full expression blue sky surface albedo}

Shuai et al., (2011) developed an algorithm to derive Landsat snow-free albedo by coupling Landsat surface reflectance with concurrent high quality MODIS BRDF information. Here we extend this method to retrieve albedo over snow covered surfaces and to calculate the full expression Landsat-8 blue sky albedo, which considers anisotropic downwelling diffuse illumination and multi-scattering effects between the surface and atmosphere which can enhance both the upwelling and downwelling radiance (Román et al., 2010; Román et al., 2013). The snow flag and cloud mask (Zhu et al., 2015; Zhu \& Woodcock, 2012) from the Landsat-8 surface reflectance product are utilized to identify cloud-free snow pixels. The Landsat-8 snow flag in the study areas agrees with MODIS snow product (MOD10A1). The albedos of snow free pixels in this study are generated using the approach of Shuai et al. (2011). The Shuai et al. (2011) method (called "MODIS-era" approach) uses an unsupervised classifier to group the individual scene into ten to fifteen clusters in Landsat multi-spectral space, then identifies the representative regions in 500-meter scale through reprojection (from UTM to MODIS sinusoidal projection) and aggregation processes. With the assumption that identical multi-spectral cluster has the similar instant anisotropy features, this "MODIS-era" approach extracts the high quality spectral BRDF estimates over representative pixels from concurrent 8-day MCD43A products (i.e. the MODIS pixels that are relatively homogenous on the Landsat- 8 scale are defined as 
representative), and introduces them back into 30-meter scale via the Albedo-to-Nadir reflectance ratio $(\mathrm{A} / \mathrm{N})$ as that show in equation (1) using Landsat-8 observation.

$$
A=\frac{a}{r\left(\Omega_{l}\right)} \cdot r_{l}
$$

Where $\Omega_{l}$ is the Landsat- 8 viewing and solar geometry, $A$ is Landsat- 8 albedo to be calculated, $a$ is the albedo derived by the BRDF parameters, $r\left(\Omega_{l}\right)$ is the reflectance derived by the BRDF parameters at the Landsat- 8 sun view geometry, and $r_{l}$ is the observed Landsat- 8 reflectance.

In this paper the anisotropy information (MCD43A1) for the acquisition date of each Landsat-8 scene is acquired from the MCD43 high quality V006 daily BRDF/NBAR/albedo products. The BRDF quality is assessed using the MCD43A2 Quality Assessment (QA) layer (Schaaf et al., 2002). The full expression blue sky albedo is calculated using a pre-defined lookup table and Aerosol Optical Depth (AOD) data (Román et al., 2010) from the MODIS MOD08 product (Remer et al., 2005). We hierarchically use the MODIS level 3 daily, 8-day, and monthly AOD data derived from both Aqua and Terra. The highest temporal resolution without a fill value is used. If no valid MODIS AOD data are available, a climatological value of 0.2 is used. For this particular study, the default climatology value was only used for the 2014 blue sky albedo calculation at sites \#6 and \#7.

Broadband shortwave albedo $(0.25-5.0 \mu \mathrm{m})$ is required for surface energy balance studies in land surface models (Roesch and Roeckner, 2006; Wang et al., 2015). Landsat data, however, are provided as multiple bands with narrow spectral ranges. For Landsat-5 and Landsat-7, narrow-tobroadband conversion coefficients were derived from laboratory spectra (Liang, 2001; Shuai et 
al., 2014) to produce the shortwave broadband albedo. For the new Landsat-8 data, we developed snow and snow-free narrow-to-broad band coefficients using the same method based on 744 spectra from USGS digital spectral library (Clark et al., 2007) and an additional 15 Analytical Spectral Devices (ASD) measured for snow spectra during field work in Antarctica in 2014-2015 (Table 3) (Casey et al., 2012). The R-squares between the VIS, NIR and SW broadband reflectances generated from the narrow-to-broadband conversion coefficients for snow-free and snow and the aggregated values directly from the library and ASD measured spectra are all larger than 0.99 .

\subsection{Landsat-8 full expression blue sky surface albedo validation}

The Landsat- 8 albedo retrievals for both snow-free and snow covered pixels were validated with in situ tower measurements at representative sites. The footprints of the tower instrumentation were calculated based on the field of view of the pyranometers and the instrument height such that:

$$
\text { Footprint diameter }=2 *(\text { tower height }) * \cos \theta
$$

Where $\theta$ is the effective field of view $\left(81^{\circ}\right)$ of the downward facing pyranometer, based on the pyranometer's cosine response and directional error (Román et al., 2009).

For all but the forested sites the vegetation height is omitted from the footprint calculation. At the Howland West and Morgan Monroe sites, the average height of the forest canopy was subtracted from the height of the tower to estimate the footprint. The ground measured albedo values are compared with the mean values of Landsat blue sky albedo within the tower 
instrumentation footprint. The cumulative Root Mean Square Error (RMSE) and bias are then calculated by comparing temporal ground albedo measurements with Landsat- 8 albedo for each site.

\subsection{Spatial heterogeneity of surface albedo and burn severity}

Detection of post-fire albedo recovery conditions during snow covered periods is challenging for high severity areas particularly when utilizing Landsat-5 and Landsat-7 due to their relatively low quality radiometric performance. Figure 5 which covers the site \#8 burn scar shows that snow covered areas without upper canopy cover in the Landsat-7 ETM+ signal are commonly saturated. However, Landsat-8 OLI, with a much improved SNR, allows for the generation of snow albedo values at landscape scales. This improvement is evident in the southern part of site \#8 where evergreen forests have pre-fire shortwave blue sky spring albedos of around 0.2-0.3. After the burn, albedo increases to more than 0.6 (reaching as high as 0.8 at some locations). The Landsat-8 signal does not saturate over this large range in values allowing for a more accurate assessment of post fire dynamics.

We explored the variation and heterogeneity of surface albedo within a fire scar by first calculating the maximum, minimum, mean, and standard deviation of the $30 \mathrm{~m}$ shortwave broadband blue sky Landsat- 8 albedo values within a moderate grid $(450 \mathrm{~m})$. A 450 m moderate grid was selected to closely match the spatial resolution of the $500 \mathrm{~m}$ MODIS products (actual grid size $=464 \mathrm{~m}$ ). The heterogeneity of the burn severity was analyzed by calculating the percentage of low, moderate, and high burn severity pixels within the corresponding $450 \mathrm{~m}$ grid 
box. The aggregated burn severity of the $450 \mathrm{~m}$ grid box was then determined by the burn condition with the highest percentage of the corresponding $30 \mathrm{~m}$ MTBS pixels.

\subsection{Post-fire albedo temporal variation}

We averaged the early spring Landsat-8 albedo values within each fire scar (Table 1) during DOY 62-94 in 2014 with valid clear Landsat-8 observations to detect post-fire albedo variation for each burn severity class. The ten sites were burn from 1984 to 2010 and thus the 2014 albedo data represents fire recovery from 4 to 30 years post-fire. Although these sites are dominated by evergreen forest, where deciduous and mixed forests were present, the post-fire albedo time series for these land covers was separately aggregated and analyzed (site \#6 and site \#9). Pre-fire and post-fire albedo values were then compared to detect changes induced by burning during the snow covered period. As Landsat-8 data are only available from early 2013 onwards, pre-fire forest albedo was calculated from Landsat-5 and Landsat-7 data (Table 1) to illustrate the variability. The pre-fire albedo values (even under snow-cover) are not generally saturated over dense forests as the forest cover dominates the signal. At these sites, Landsat- 5 and -7 derived albedo values are typically around $0.2-0.3$. While Shuai et al. (2014) has demonstrated a retrieval method for historical Landsat surface albedo using MODIS-based a-priori anisotropy knowledge during snow free periods for pre- MODIS era, we have only generated pre-fire albedos for sites that were burned after the year 2000 using the MODIS MCD43A BRDF model parameters.

\section{Results and Discussions}

\subsection{Landsat-8 full expression blue sky albedo validation}


The overall RMSE of the combined snow and snow-free data is 0.0267 with a bias of 0.0031 between Landsat-8 albedo and ground measurements. Separately, the RMSE and bias for snow scenes were 0.0426 and -0.0013 respectively and for the snow-free scenes was 0.0191 and 0.0037 respectively (Figure 6, Table 4). The RMSE for the snow-free sites was in-line with the results originally presented by Shuai et al (2011) for the earlier Landsat missions. At the two forested sites, Landsat- 8 albedo retrievals are slightly higher than the tower data, with a slightly positive bias of 0.0074 and 0.0168 for snow and snow-free scenes respectively. The low profile vegetation sites (grassland and tundra) show a negligible bias of - -0.0006 and RMSE of 0.0185 for snow-free scenes and a bias of -0.0001 and RMSE of 0.0467 for snow scenes, well within the expected accuracy range of the product. The blue sky snow albedo derived from 12-bit Landsat-8 OLI with improved signal-to-noise ratios show better accuracy than glacier albedo estimated from Landsat-5 TM, Landsat-7 ETM+ and MODIS (MOD10A) in which the RMSEs were larger than 0.05 (Dumont et al., 2012; Klok et al., 2003; Lhermitte et al., 2014).

While not located at the actual post fire burn sites, these tower based validation assessments indicates the accuracy of the Landsat- 8 albedo product under both snow-free and snow-covered conditions is acceptable and supports the use of these data to investigate the albedo dynamics of heterogeneous and snow cover landscapes.

\subsection{Surface albedo and burn severity heterogeneity at fire scar scale}

Although the study areas are dominated by forest with very few other vegetation types present (shrub and grass), the spatial heterogeneity of albedo is still high at the landscape scale (Figure 7). In addition, changes in forest structure, especially after a disturbance and during snow cover, 
can lead to highly varying albedo between different forests. Figure 8 shows the fire scar at site \#7 re-gridded to the MODIS approximate $450 \mathrm{~m}$ grid. The minimum, maximum, mean, and standard deviation of the Landsat-8 albedo within each grid cell are shown for DOY 2014094. Most minimum values are less than 0.4 while the maximum values are higher than 0.5 and can reach 0.8 or more. The standard deviation of albedo within the MODIS grid is around 0.1 which illustrates that potentially valuable information on ecosystems trends and recovery dynamics can be lost when utilizing a coarser resolution grid resolution. Within the $450 \mathrm{~m}$ moderate grid, no single burn severity class significantly dominates the burn scar (Figure 9) and low and moderate burn severity areas comprise close to $30 \%$ of most of the gridded cells.

In mixing these low and high signals within moderate resolution imagery, valuable information on the effect of different burn severities can be lost. Mixed-severity fires scars typically have higher beta-diversity and result in more complex landscapes with variation in vegetation patches driven by fire severity and fire history (Taylor and Skinner, 1998). In addition, disturbance patterns and stand regrowth vary geographically as does the proportion of different severity classes within a scar (Spies and Franklin, 1989; Veblen, 1989; Veblen et al., 1992). As such, higher resolution information across latitudinal and ecosystem gradients is valuable for management decisions on fire mitigation and control (Taylor and Skinner, 1998). Mixed severity burn histories also contribute to more structurally diverse late successional conditions in forest stands which are both more resistant to future fires and provide greater habitats for wildlife (Taylor and Skinner, 1998). For regional land surface models or energy budget and climate forcing analysis, coarse spatial resolution values lose the fine scale albedo variation caused by surface heterogeneity which can significantly affect the soil properties and post fire vegetation 
recovery. As such, identifying and characterizing fire severity and variation in recovery patterns can provide valuable information across a range of ecological and management interests. In the six sites burned in 2004 and 2010, the mean post-fire albedo over severely burned forest from 30 $\mathrm{m}$ Landsat- 8 data is 0.60 with some values reaching as high as 0.7 . This is slightly higher than the values of 0.57 from aggregated $450 \mathrm{~m}$ Landsat- 8 data and 0.55 reported in Jin et al. (2012a) using MODIS albedos alone. This muting of the albedo range mainly results from the fine scale heterogeneity of burn severity and albedo. Larger MODIS pixels assigned to a high burn severity designation usually also contain areas of low or moderate burn severity, and as such, the albedo calculated from coarse spatial resolution MODIS pixels over high burn severity area is lower than the values determined by the individual $30 \mathrm{~m}$ Landsat- 8 pixels classified as high burn severity areas. Thus, fine spatial resolution albedo enhances the ability to detect the post-fire vegetation dynamics at a full range of burn severity levels. In addition, as fire severity is expected to increase, this finer resolution data set allows more detailed projections and modeling of severity effects on the landscape scale.

The heterogeneity in albedo and the link to burn severity and vegetation is further evident in an $8.4 \mathrm{~km}$ transect analyzed at site \#10 (Figure 2). The pre-fire and post-fire albedo values and corresponding severity classes along this transect are shown in Figure 10. The full expression shortwave blue sky albedo varies from less than 0.1 to greater than 0.7 . This range in albedo occurs within a $450 \mathrm{~m}$ segment of the transect (Figure 2, Segment A), indicating very high spatial heterogeneity. This heterogeneity is driven by a combination of landscape characteristics, fire severity and vegetation dynamics post fire. For instance, in the last $900 \mathrm{~m}$ of the $8.4 \mathrm{~km}$ transect (Figure 2, Figure 10, Segment B), the pre-fire snow albedo values are relatively stable without 
demonstrating a significant trend and the albedo values of most pixels are within a range of 0.20.3 while post-fire snow albedo values increase from 0.30 to 0.65 . This segment is completely within an area classified as associated with a high burn severity and suggests that although burn severity is certainly a driver of post-fire albedo, significant variation in snow albedo within each burn severity class still exists. Thus the variability of burned fraction can be large within the same burn severity designation (Veraverbeke et. al 2014) which can contribute a variation of albedo associated with that burn severity. Within each burn severity class, albedo variation is primarily driven by vegetation dynamics and the extent of surface snow exposure as post-fire vegetation remnants with heights greater than the snow depth strongly influence albedo value (Liu et al., 2005; Amiro et al., 2006; Lyons et al., 2008; O’Halloran et al., 2014). This is also evident in the recovery of less severely burned areas. For instance, the dominant burn condition at site \#2, which burned in 1989, was high burn severity; with scattered areas of moderate and low burn severity in the northern and southern ends of the scar (Figure 2). In the northern portion of the scar, these less severely burned areas have low early spring albedos more on par with a forested or unburned land cover $(\sim 0.3-0.5)$. We posit that within these less severely burned areas there was less structural disruption and mortality of the standing trees. In contrast, the post-fire albedo over the low and moderate burn severity area in the southern end of the fire scar has a comparatively higher albedo ( 0.6-0.7), and a post-fire land cover of shrub and scrub land. These differing post fire albedo patterns show that post-fire vegetation species have a strong impact on albedo and that burn severity alone is not a sufficient indicator of recovery dynamics.

The effect of different forest types on the characteristics of albedo and burn severity is further analyzed at sites where deciduous and mixed forest classes are present (site \#6 and site \#9). The 
results indicate that within each severity class the pre-fire forest type does not necessarily lead to a significant difference in post-fire albedo (Table 5). Nevertheless, albedo generally increases from low burn severity to high burn severity over all these forest types.

\subsection{Post-fire albedo temporal variation}

Fire and fire severity play an important role in early spring albedo values, which influences snowmelt and localized atmospheric warming. Post fire albedo recovery within a fire scar are impacted both by burn severity and vegetation dynamics. The 2014 early spring albedo values were generally higher in the more recently burned fire scars (2004 and 2010) than in fires that burned prior to 1998 (Figure 11). These differences were primarily driven by the vegetation recovery as grasslands were replaced by more shrub and scrub dominated land covers (Zhang et al., 2013). For sites burned in 2004 or 2010, high severity areas show the highest albedo. Albedo decreased in conjunction with burn severity such that the albedo in moderate and low severity burns exhibited mid-range and low albedo values respectively. The 2004 and 2010 fires sites were used to assess the albedo differences pre and post fire with pre fire albedo calculated from Landsat-5 and Landsat-7 data prior to the fire. The 2004 and 2010 fire sites represent a ten and four year albedo recovery respectively. We found that fire events increase the early spring albedo by $22 \%-83 \%$, with the differences between the pre-fire and post-fire mean albedo ranging from 0.09 to 0.24 . The albedo changes in the 2004 fires scars $(0.16,0.24$, and 0.24 for sites \#5, \#6, and \#7 respectively) were greater than the changes seen in the 2010 fires $(0.21,0.09$ and 0.10 for sites \#8, \#9 and \#10 respectively). Although two dates of pre-fire and post-fire albedo comparison can not provide a full analysis of post fire albedo trajectories (Veraverbeke et al., 2010, 2012; Lhermitte et al., 2010) and the study areas (such as the ten sites burned from 
year 1984 to 2010 used here) are limited, these post-fire albedo patterns deduced from the Landsat data capture similar trends with those presented in previous studies from MODIS (Randerson et al., 2006; Jin et al., 2012a), and suggest that the difference between pre-fire and post-fire albedo increases with time during the first few years of recovery. This pattern may be driven in part by the continued loss of branches and standing dead boles (Bond-Lamberty and Gower, 2008) in the years immediately post fire.

Although the periods are necessarily constrained to DOY 062-094 in 2014 due to the short lifespan of Landsat-8, differences in snow density, impurities, and grain size between the sites may also influence the snow albedo (Aoki et al., 2000;Wiscombe \& Warren, 1980) and contribute to the uncertainty of cross-sites comparison, while the early spring albedo values are dominated by the vegetation status.

\section{Conclusion}

The availability of high quality, high SNR Landsat-8 OLI measurements which eliminate the saturation due to 12-bit signal over snow surface improves the analysis of post-fire albedo recovery at the landscape $(<100 \mathrm{~m})$ scale; especially during early spring snow covered periods over high burn severity areas where previous 8-bit Landsat-5 and Landsat-7 sensors often saturate. The OLI land surface full expression shortwave blue-sky albedo is generated through the use of narrow-to-broadband conversion coefficients generated from USGS spectral library and ASD measured snow spectra collected in Antarctica. Although tower data are not available for any of the burn sites, the full expression shortwave blue-sky albedo is validated in general at six spatially representative tower sites with an overall accuracy of 0.0267 . Post-fire albedo 
recovery analyses capture similar trends with previous studies, and show that the difference between pre-fire and post-fire albedo increases with time during the first few years of recovery. Both burn severity and early spring albedo show significant post-fire spatial heterogeneity at the landscape-level in the high latitude boreal forests of Alaska. We found that the albedo can range from 0.1 to 0.7 or higher within a single MODIS gridded pixel. The post-fire albedo values are highly related to burn severity classification with snow albedo post-fire generally increasing with severity class. Early spring mean albedo from Landsat- 8 data in areas of high burn severity is 0.60 for the sites burned in 2004 and 2010. This is larger than the values obtained from MODIS scale resolution albedo at similar locations. This occurs because the MODIS pixel, although classified as predominantly high burn severity, may still include low or moderate severity burn areas due to high spatial heterogeneity. This results in an overall lower MODIS albedo value for high severity burned areas as revealed by the $30 \mathrm{~m}$ Landsat- 8 albedo values when compared at a landscape scale. Thus, the ability to generate fine spatial resolution albedo from the high quality Landsat-8 data enhances the ability to detect the post-fire vegetation patterns at different burn severity levels.

Changes in albedo and land cover in boreal systems post-fire persist for long periods of time and the cumulative effect of these changes can greatly influence the energy balance. Long term fine spatial resolution land cover datasets are necessary to monitor the post-fire vegetation and determine albedo recovery. The impact of topography, soil type and the impact of these land cover and burn severity datasets on post-fire energy budgets should be further analyzed. Early spring albedo is highly influenced by the canopy status above the snow depth. Therefore, the use 
of airborne Lidar data, which provides high quality aboveground canopy height, would also significantly benefit future post-fire energy balance and ecosystem studies.

However, this study demonstrates that the continued Landsat- 8 data record, along with access to the new, even higher resolution, Sentinel-2 data, will significantly further a deeper understanding of these high latitude systems.

\section{Acknowledgements:}

This research was supported by NASA awards NNX14A173G and USGS award G12PC00072. The MODIS data were obtained from the NASA Distributed Active Archive Centers (DAACs). The Landsat data were obtained from the USGS Earth Resources Observation and Science (EROS) Center Science Processing Architecture (ESPA). Field albedo measurements were downloaded from NOAA SURFRAD. We gratefully acknowledge Dr. Adrian Rocha from University of Notre Dame for providing ground albedo measurements at the Imnavait site, Dr. David Y. Hollinger from USDA Forest Service Northern Research Station, Durham, NH, USA for providing ground albedo measurements at the Howland West site and Dr. Kimberly Novick and Dr. Benjamin Sulman from Indiana University for providing ground albedo measurements at the Morgan Monroe State Forest site which was supported primarily by the Office of Science (BER), US Department of Energy through the Ameriflux Management Project.

\section{Reference:}

Amiro, B. D., Orchansky, A. L., Barr, A. G., Black, T. A., Chambers, S. D., Chapin, F. S., ... Randerson, J. T. (2006). The effect of post-fire stand age on the boreal forest energy balance. 
Agricultural and Forest Meteorology, 140(1-4), 41-50.

http://doi.org/10.1016/j.agrformet.2006.02.014

Aoki, T., Aoki, T., Fukabori, M., Hachikubo, A., Tachibana, Y., \& Nishio, F. (2000). Effects of snow physical parameters on spectral albedo and bidirectional reflectance of snow surface. Journal of Geophysical Research. http://doi.org/10.1029/1999JD901122

Augustine, J. A., DeLuisi, J., \& Long, C. (2000). SURFRAD: A national surface radiation budget network for atmospheric research. Bulletin of the American Meteorological Society, 81 (10), 2341-2357. doi:10.1175/1520-0477(2000)081b2341:SANSRBN2.3.co;2.

Bala, G., Caldeira, K., Wickett, M., Phillips, T. J., Lobell, D. B., Delire, C., \& Mirin, A. (2007). Combined climate and carbon-cycle effects of large-scale deforestation. Proceedings of the National Academy of Sciences of the United States of America, 104(16), 6550-6555. http://doi.org/10.1073/pnas.0608998104

Balshi, M. S., McGuire, a. D., Zhuang, Q., Melillo, J., Kicklighter, D. W., Kasischke, E., ... Shvidenko, a. (2007). The role of historical fire disturbance in the carbon dynamics of the pan-boreal region: A process-based analysis. Journal of Geophysical Research:

Biogeosciences, 112(2), 1-18. http://doi.org/10.1029/2006JG000380

Balshi, M. S., Mcguire, A. D., Duffy, P., Flannigan, M., Kicklighter, D. W., \& Melillo, J. (2009). Vulnerability of carbon storage in North American boreal forests to wildfires during the 21st century. Global Change Biology, 15(6), 1491-1510. http://doi.org/10.1111/j.13652486.2009.01877.x 
Berk, A., Cooley, T.W., Anderson, G.P., Acharya, P.K., Bernstein, L.S., Muratov, L., Lee, J., Fox, M.J., Adler-Golden, S.M., Chetwynd, J.H., Hoke, M.L., Lockwood, R.B., Gardner, J.A., \& Lewis, P.E. (2004). MODTRAN5: A Reformulated Atmospheric Band Model with Auxiliary Species and Practical Multiple Scattering Options, Sensors, Systems, and NextGeneration Satellites. In, VIII. Proceedings of the Society of Photographic Instrumentation Engineers (SPIE) (pp. 78-85)

Beck, P. S. A., Goetz, S. J., Mack, M. C., Alexander, H. D., Jin, Y., Randerson, J. T., \& Loranty, M. M. (2011). The impacts and implications of an intensifying fire regime on Alaskan boreal forest composition and albedo. Global Change Biology, 17(9), 2853-2866. http://doi.org/10.1111/j.1365-2486.2011.02412.x

Bond-Lamberty, B., Peckham, S. D., Ahl, D. E., \& Gower, S. T. (2007). Fire as the dominant driver of central Canadian boreal forest carbon balance. Nature, 450(7166), 89-92. http://doi.org/10.1038/nature06272

Bond-Lamberty, B., and Gower, S. T. (2008), Decomposition and fragmentation of coarse woody debris: Re-visiting a boreal black spruce chronosequence, Ecosystems, 11(6), 831840, doi:10.1007/s10021-008-9163-y.

Bowman, D. M. J. S., Balch, J. K., Artaxo, P., Bond, W. J., Carlson, J. M., Cochrane, M. A., ... Pyne, S. J. (2009). Fire in the Earth system. Science (New York, N.Y.), 324(5926), 481-484. http://doi.org/10.1126/science.1163886

Brovkin, V., Sitch, S., von Bloh, W., Claussen, M., Bauer, E., \& Cramer, W. (2004). Role of land cover changes for atmospheric $\mathrm{CO} 2$ increase and climate change during the last 150 
years. Global Change Biology, 10(8), 1253-1266. http://doi.org/10.1111/j.13652486.2004.00812.x

Casey, K. A., Kääb, A., \& Benn, D. (2012) Geochemical characterization of glacier debris via in situ and optical remote sensing methods: a case study in the Khumbu Himalaya Nepal. The Cryosphere, 6: 85-100.

Chambers, S. D., \& Chapin, F. S. (2002). Fire effects on surface-atmosphere energy exchange in Alaskan black spruce ecosystems: Implications for feedbacks to regional climate. Journal of Geophysical Research. http://doi.org/10.1029/2001JD000530

Clark, R.N., Swayze, G.A., Wise, R., Livo, E., Hoefen, T., Kokaly, R., \&Sutley, S.J., (2007). USGS digital spectral library splib06a: U.S. Geological Survey, Digital Data Series 231, http://speclab.cr.usgs.gov/spectral.lib06

Duffy, P. A., Epting, J., Graham, J. M., Rupp, T. S., \& McGuire, A. D. (2007). Analysis of Alaskan burn severity patterns using remotely sensed data. International Journal of Wildland Fire, 16(3), 277-284. http://doi.org/doi:10.1071/WF06034

Dumont, M., Gardelle J., Sirguey P., Guillot A., Six D., Rabatel A., \& Arnaud Y. (2012), Linking glacier annual mass balance and glacier albedo retrieved from MODIS data, The Cryosphere, 6, 1527-1539

Eidenshink, J., Schwind, B., Brewer, K., Zhu, Z.-L., Quayle, B., \& Howard, S. (2007). A Project for Monitoring Trends in Burn Severity. Fire Ecology. http://doi.org/10.4996/fireecology.0301003 
Epting, J., \& Verbyla, D. (2005). Landscape-level interactions of prefire vegetation, burn severity, and postfire vegetation over a 16-year period in interior Alaska. Canadian Journal of Forest Research. http://doi.org/10.1139/x05-060

Epting, J., Verbyla, D., \& Sorbel, B. (2005). Evaluation of remotely sensed indices for assessing burn severity in interior Alaska using Landsat TM and ETM+. Remote Sensing of Environment, 96(3-4), 328-339. http://doi.org/10.1016/j.rse.2005.03.002

Flanner, M. G., Shell, K. M., Barlage, M., Perovich, D. K., \& Tschudi, M. a. (2011). Radiative forcing and albedo feedback from the Northern Hemisphere cryosphere between 1979 and 2008. Nature Geoscience, 4(3), 151-155. http://doi.org/10.1038/ngeo1062

Flannigan, M. D., Logan, K. A., Amiro, B. D., Skinner, W. R., \& Stocks, B. J. (2005). Future area burned in Canada. Climatic Change, 72(1-2), 1-16. http://doi.org/10.1007/s10584-005$5935-\mathrm{y}$

Foote, M. J. (1983), Classification, description, and dynamics of plant communities after fire in the taiga of interior Alaska, Res. Pap. PNW-307, p. 116, U.S. Dep. of Agric., Portland, Oreg.

French, N. H. F., Kasischke, E. S., Hall, R. J., Murphy, K. A., Verbyla, D. L., Hoy, E. E., \& Allen, J. L. (2008). Using Landsat data to assess fire and burn severity in the North American boreal forest region: an overview and summary of results. International Journal of Wildland Fire, 17(4), 443-462. http://doi.org/doi:10.1071/WF08007 
Gao, B. C., Goetz, A. F., \& Wiscombe, W. J. (1993). Cirrus cloud detection from airborne imaging spectrometer data using the $1.38 \mu \mathrm{m}$ water vapor band. Geophysical Research Letters, 20(4), 301-304

García, M. J. L., \& Caselles, V. (1991). Mapping burns and natural reforestation using thematic Mapper data. Geocarto International. http://doi.org/10.1080/10106049109354290

Gillett, N. P., Weaver, A. J., Zwiers, F. W., \& Flannigan, M. D. (2004). Detecting the effect of climate change on Canadian forest fires. Geophysical Research Letters, 31(18). http://doi.org/10.1029/2004GL020876

Goetz, S. J., Mack, M. C., Gurney, K. R., Randerson, J. T., \& Houghton, R. A. (2007). Ecosystem response to recent climate change and fire disturbance at northern high latitudes: Observations and model results contrasting northern Eurasia and North America. Environmental Research Letters, 2, 1-9.

Goetz, S. J., Bond-Lamberty, B., Law, B. E., Hicke, J. A., Huang, C., Houghton, R. A., ... Kasischke, E. S. (2012). Observations and assessment of forest carbon dynamics following disturbance in North America. Journal of Geophysical Research: Biogeosciences, 117(2). http://doi.org/10.1029/2011JG001733

Hall, D. K., Riggs, G. A., Salomonson, V. V., DiGirolamo, N. E., \& Bayr, K. A. (2002). MODIS snow-cover products. Remote Sensing of Environment, 83, 181 - 194.

Hinzman, L. D., Bettez, N. D., Bolton, W. R., Chapin, F. S., Dyurgerov, M. B., Fastie, C. L., ... Yoshikawa, K. (2005). Evidence and implications of recent climate change in northern 
Alaska and other arctic regions. Climatic Change, 72(3), 251-298.

http://doi.org/10.1007/s10584-005-5352-2

Homer, C., Dewitz, J., Fry, J., Coan, M., Hossain, N., Larson, C., Herold, N., McKerrow, A., VanDriel, J.N., and Wickham, J. (2007), Completion of the 2001 National Land Cover Database for the Conterminous United States. Photogrammetric Engineering and Remote Sensing, 73, 337-341.

Huang, S., Jin, S., Dahal, D., Chen, X., Young, C., Liu, H., \& Liu, S. (2013). Reconstructing satellite images to quantify spatially explicit land surface change caused by fires and succession: A demonstration in the Yukon River Basin of interior Alaska. ISPRS Journal of Photogrammetry and Remote Sensing, 79, 94-105.

http://doi.org/10.1016/j.isprsjprs.2013.02.010

Jin, Y., Randerson, J. T., Goulden, M. L., \& Goetz, S. J. (2012a). Post-fire changes in net shortwave radiation along a latitudinal gradient in boreal North America. Geophysical Research Letters, 39(13), 1-7. http://doi.org/10.1029/2012GL051790

Jin, Y., Randerson, J. T., Goetz, S. J., Beck, P. S. a, Loranty, M. M., \& Goulden, M. L. (2012b). The influence of burn severity on postfire vegetation recovery and albedo change during early succession in North American boreal forests. Journal of Geophysical Research: Biogeosciences, 117(1), 1-15. http://doi.org/10.1029/2011JG001886

Johnstone, J. F., \& Chapin, F. S. (2006). Effects of soil burn severity on post-fire tree recruitment in boreal forest. Ecosystems, 9(1), 14-31. http://doi.org/10.1007/s10021-004-0042-x 
Johnstone, J. F., Hollingsworth, T. N., Chapin, F. S., \& Mack, M. C. (2010). Changes in fire regime break the legacy lock on successional trajectories in Alaskan boreal forest. Global Change Biology, 16(4), 1281-1295. http://doi.org/10.1111/j.1365-2486.2009.02051.x

Kasischke, E. S., \& Turetsky, M. R. (2006). Recent changes in the fire regime across the North American boreal region - Spatial and temporal patterns of burning across Canada and Alaska. Geophysical Research Letters, 33(9). http://doi.org/10.1029/2006GL025677

Key, C.H., and N.C. Benson. 2006. Landscape assessment: sampling and analysis methods. USDA Forest Service, Rocky Mountain Research Station General Technical Report RMRSGTR-164-CD

Klok, E. J., Greuell W., \& Oerlemans J. (2003), Temporal and spatial variation of the surface albedo of Morteratschgletscher, Switzerland, as derived from 12 Landsat images, Journal of Glaciology, 49, 491-502

Lawrence, D. M., \& Swenson, S. C. (2011). Permafrost response to increasing Arctic shrub abundance depends on the relative influence of shrubs on local soil cooling versus largescale climate warming. Environmental Research Letters. http://doi.org/10.1088/1748$9326 / 6 / 4 / 045504$

Lhermitte, S., Verbesselt J., Verstraeten W. W., \& Coppin P. (2010). A Pixel Based Regeneration Index using Time Series Similarity and Spatial Context, Photogrammetric Engineering \& Remote Sensing, 76, 673 - 682 
Lhermitte, S., Verbesselt J., Verstraeten W. W., Veraverbeke S., Coppin P. (2011), Assessing intra-annual vegetation regrowth after fire using the pixel based regeneration index, ISPRS Journal of Photogrammetry and Remote Sensing, 66(1), 17-27. doi:10.1016/j.isprsjprs.2010.08.004

Lhermitte S., Abermann J., \& Kinnard C. (2014). Albedo over rough snow and ice surfaces, The Cryosphere, 8, 1069 - 1086

Liang, S. (2001). Narrowband to broadband conversions of land surface albedo: I. Algorithms. Remote Sensing for Environmental, 76, 213-238

Liu, H., Randerson, J. T., Lindfors, J., \& Chapin, F. S. (2005). Changes in the surface energy budget after fire in boreal ecosystems of interior Alaska: An annual perspective. Journal of Geophysical Research: Atmospheres, 110(13). http://doi.org/10.1029/2004JD005158

Loranty, M. M., Goetz, S. J., \& Beck, P. S. A. (2011). Tundra vegetation effects on pan-Arctic albedo. Environmental Research Letters. http://doi.org/10.1088/1748-9326/6/2/029601

Lucht, W., \& Lewis, P. (2000). Theoretical noise sensitivity of BRDF and albedo retrieval from the EOS-MODIS and MISR sensors with respect to angular sampling. International Journal of Remote Sensing, 21(1), $81-98$.

Lutz, J. A., Key, C. H., Kolden, C. A., Kane, J. T., \& van Wagtendonk, J. W. (2011). Fire frequency, area burned, and severity: A quantitative approach to defining a normal fire year. Fire Ecology, 7(2), 51-65. http://doi.org/10.4996/fireecology.0702051 
Lyons, E. A., Jin, Y., \& Randerson, J. T. (2008). Changes in surface albedo after fire in boreal forest ecosystems of interior Alaska assessed using MODIS satellite observations. Journal of Geophysical Research, 113(G2), 1-15. http://doi.org/10.1029/2007JG000606

Mack, M. C., Treseder, K. K., Manies, K. L., Harden, J. W., Schuur, E. A. G., Vogel, J. G., ... Chapin, F. S. (2008). Recovery of aboveground plant biomass and productivity after fire in mesic and dry black spruce forests of interior Alaska. Ecosystems, 11(2), 209-225. http://doi.org/10.1007/s10021-007-9117-9

Masek, J. G., Vermote, E. F., Saleous, N. E., Wolfe, R., Hall, F. G., Huemmrich, K. F., ... Lim, T. (2006). A Landsat Surface Reflectance Dataset. IEEE Geoscience and Remote Sensing Letters, 3(1), 68-72.

McGuire, A. D., et al. (2004), Land cover disturbances and feedbacks to the climate system in Canada and Alaska, in Land Change Science, edited by G. Gutman et al., pp. 139-161 pp., Springer, Dordrecht, Netherlands.

McGuire, A. D., Chapin, F. S., Walsh, J. E., \& Wirth, C. (2006). Integrated Regional Changes in Arctic Climate Feedbacks: Implications for the Global Climate System. Annual Review of Environment and Resources, 31(1), 61-91.

http://doi.org/10.1146/annurev.energy.31.020105.100253

NWCG [National Wildfire Coordinating Group] 2005. Glossary of Wildland Fire Terminology. National Interagency Fire Center. Boise,Idaho http://www.nwcg.gov/pms/pubs/pubs.htm \#PMS205 (accessed April, 2015). 
O’Halloran, T. L., Acker S. A., Joerger V. M., Kertis J., \& Law B. E. (2014), Postfire influences of snag attrition on albedo and radiative forcing, Geophysical Research Letters, doi: 10.1002/2014GL062024

Randerson, J. T., Liu, H., Flanner, M. G., Chambers, S. D., Jin, Y., Hess, P. G., ... Zender, C. S. (2006). The impact of boreal forest fire on climate warming. Science (New York, N.Y.), 314(5802), 1130-1132. http://doi.org/10.1126/science.1132075

Remer, L. a., Kaufman, Y. J., Tanré, D., Mattoo, S., Chu, D. a., Martins, J. V., ... Holben, B. N. (2005). The MODIS Aerosol Algorithm, Products, and Validation. Journal of the Atmospheric Sciences, 62(4), 947-973. http://doi.org/10.1175/JAS3385.1

Roesch, A., and Roeckner. E, 2006: Assessment of Snow Cover and Surface Albedo in the ECHAM5 General Circulation Model. Journal of Climate, 19, 3828-3843. doi: http://dx.doi.org/10.1175/JCLI3825.1

Rocha, A. V., \& Shaver, G. R. (2011). Postfire energy exchange in arctic tundra: The importance and climatic implications of burn severity. Global Change Biology, 17(9), 2831-2841. http://doi.org/10.1111/j.1365-2486.2011.02441.x

Román, M. O., Schaaf, C. B., Woodcock, C. E., Strahler, A. H., Yang, X., Braswell, R. H., ... Goulden, M. L. (2009). The MODIS (Collection V005) BRDF/albedo product: Assessment of spatial representativeness over forested landscapes. Remote Sensing of Environment, 113(11), 2476-2498. http://doi.org/10.1016/j.rse.2009.07.009 
Román, M. O., Schaaf, C. B., Lewis, P., Gao, F., Anderson, G. P., Privette, J. L., ... Barnsley, M. (2010). Assessing the coupling between surface albedo derived from MODIS and the fraction of diffuse skylight over spatially-characterized landscapes. Remote Sensing of Environment, 114(4), 738-760. http://doi.org/10.1016/j.rse.2009.11.014

Román, M. O., Gatebe, C. K., Schaaf, C. B., Poudyal, R., Wang, Z., \& King, M. D. (2011). Variability in surface BRDF at different spatial scales (30m-500m) over a mixed agricultural landscape as retrieved from airborne and satellite spectral measurements. Remote Sensing of Environment, 115, 2184-2203. http://doi.org/10.1016/j.rse.2011.04.012

Román, M. O., Gatebe, C. K., Shuai, Y., Wang, Z., Gao, F., Masek, J. G., Schaaf, C. B. (2013). Use of in situ and airborne multiangle data to assess MODIS- and landsat-based estimates of directional reflectance and albedo. IEEE Transactions on Geoscience and Remote Sensing, 51, 1393-1404. http://doi.org/10.1109/TGRS.2013.2243457

Roy, D. P., Wulder, M. A., Loveland, T. R., C.E., W., Allen, R. G., Anderson, M. C., ... Zhu, Z. (2014). Landsat-8: Science and product vision for terrestrial global change research. Remote Sensing of Environment, 145, 154-172. http://doi.org/10.1016/j.rse.2014.02.001

Schaaf, C. B., Gao, F., Strahler, A. H., Lucht, W., Li, X., Tsang, T., et al. (2002). First operational BRDF, albedo, nadir reflectance products from MODIS. Remote Sensing of Environment, 83, 135-148.

Schaaf, C. L. B., Liu, J., Gao, F., \& Strahler, A. H. (2011). MODIS albedo and reflectance anisotropy products from Aqua and Terra. In B. Ramachandran, C. Justice, \& M. Abrams (Eds.), Land remote sensing and global environmental change: NASA's Earth observing 
system and the science of ASTER and MODIS. Remote Sensing and Digital Image Processing Series, Vol. 11, . Springer-Verlag (873 pp.).

Schmidt, G.L., Jenkerson, C.B., Masek, J., Vermote, E., and Gao, F. (2013), Landsat ecosystem disturbance adaptive processing system (LEDAPS) algorithm description: U.S. Geological Survey Open File Report 2013 1057, 17 p.

Shenoy, A., Johnstone, J. F., Kasischke, E. S., \& Kielland, K. (2011). Persistent effects of fire severity on early successional forests in interior Alaska. Forest Ecology and Management, 261(3), 381-390. http://doi.org/10.1016/j.foreco.2010.10.021

Shuai, Y., Masek, J. G., Gao, F., \& Schaaf, C. B. (2011). An algorithm for the retrieval of 30-m snow-free albedo from Landsat surface reflectance and MODIS BRDF. Remote Sensing of Environment, 115(9), 2204-2216. http://doi.org/10.1016/j.rse.2011.04.019

Shuai, Y., Masek, J. G., Gao, F., Schaaf, C. B., \& He, T. (2014). An approach for the long-term 30-m land surface snow-free albedo retrieval from historic Landsat surface reflectance and MODIS-based a priori anisotropy knowledge. Remote Sensing of Environment, 152, 467479. http://doi.org/10.1016/j.rse.2014.07.009

Shuai, Y., Schaaf, C., Zhang, X., Strahler, A., Roy, D., Morisette, J., ... Davies, J. E. (2013). Daily MODIS $500 \mathrm{~m}$ reflectance anisotropy direct broadcast (DB) products for monitoring vegetation phenology dynamics. International Journal of Remote Sensing, 34, 5997-6016. http://doi.org/10.1080/01431161.2013.803169 
Spies, T.A. and Franklin, J.F., (1989). Gap characteristics and vegetation response in coniferous forests of the Pacific Northwest. Ecology 70, 543-545.

Stehman, S. V., \& Selkowitz, D. J. (2010). A spatially stratified, multi-stage cluster sampling design for assessing accuracy of the Alaska (USA) National Land Cover Database (NLCD). International Journal of Remote Sensing, 31, 1877-1896, http://doi.org/10.1080/01431160902927945

Sturm, M., Douglas, T., Racine, C. and Liston, G. E. (2005), Changing snow and shrub conditions affect albedo with global implications, Journal of Geophysical Research., 110, G01004, doi:10.1029/2005JG000013.

Taylor, A. H. and Skinner C. N. (1998), Fire history and landscape dynamics in the latesuccessional reserve, Klamath Mountains, California, USA, Forest Ecology and Management, 111, 285-301

Turetsky, M. R., Donahue, W. F., \& Benscoter, B. W. (2011). Experimental drying intensifies burning and carbon losses in a northern peatland. Nature Communications. http://doi.org/10.1038/ncomms 1523

Veblen, T.T., (1989). Tree regeneration responses to gaps along a transandean gradient. Ecology $70,541-543$.

Veblen, T.T., Kitzburger, T., Lara, A., (1992). Disturbance and forest dynamics along a transect from Andean rainforest to Patagonian shrubland, Journal of Vegetation Science, 3, 507-520. 
Veraverbeke, S., Lhermitte S., Verstraeten W. W., Goossens R. (2010). The temporal dimension of differenced Normalized Burn Ratio (dNBR) fire/burn severity studies: The case of the large 2007 Peloponnese wildfires in Greece, Remote Sensing of Environment, 114, 2548 2563

Veraverbeke, S., Lhermitte S., Verstraeten W. W., Goossens R. (2011). A tme-integrated MODIS burn severity assessment using the multi-temporal differenced normalized burn ratio $\left(\mathrm{dNBR}_{\mathrm{MT}}\right)$, International Journal of Applied Earth Observation and Geoinformation, $13,52-58$

Veraverbeke, S., Verstraeten W. W., Lhermitte S., Kerchove R. V. D., Goosens R. (2012). Assessment of post-fire changes in land surface temperature and surface albedo, and their relation with fire - burn severity using multitemporal MODIS imagery. Journal of Wildland Fire, 21, 243-256.

Veraverbeke, S., Natasha Stavros E., Hook S. J. (2014), Assessing fire severity using imaging spectroscopy data from the Airborne Visible/Infrared Imaging Spectrometer (AVIRIS) and comparison with multispectral capabilities, Remote Sensing of Environment, 154,153-163.

Viereck, L. A. (1973), Wildfire in the taiga of Alaska, Quaternary Research, 3, 465-495, doi:10.1016/0033-5894(73)90009-4.

Vogelmann, J. E., Sohl, T. L., Campbell, P. V., \& Shaw, D. M. (1998). Regional land cover characterization using Landsat thematic mapper data and ancillary data sources. Environmental Monitoring and Assessment, 51, 415-428. http://doi.org/10.1023/A:1005996900217 
Wang, T., Peng S., Krinner G., Ryder J., Li Y., Dantec-Nédélec S., \& Ottlé C. (2015) Impacts of SatelliteBased Snow Albedo Assimilation on Offline and Coupled Land Surface Model Simulations. PLoS ONE 10(9): e0137275. doi:10.1371/journal. pone.0137275

Wang, Z., Schaaf, C. B., Chopping, M. J., Strahler, A. H., Wang, J., Román, M. O., ... Shuai, Y. (2012). Evaluation of Moderate-resolution Imaging Spectroradiometer (MODIS) snow albedo product (MCD43A) over tundra. Remote Sensing of Environment, 117, 264-280. http://doi.org/10.1016/j.rse.2011.10.002

Wang, Z., Schaaf, C. B., Strahler, A. H., Chopping, M. J., Román, M. O., Shuai, Y., ... Fitzjarrald, D. R. (2014). Evaluation of MODIS albedo product (MCD43A) over grassland, agriculture and forest surface types during dormant and snow-covered periods. Remote Sensing of Environment, 140, 60-77. http://doi.org/10.1016/j.rse.2013.08.025

Warren, S. G., \& Wiscombe, W. J. (1980). A Model for the Spectral Albedo of Snow. II: Snow Containing Atmospheric Aerosols. Journal of the Atmospheric Sciences. http://doi.org/10.1175/1520-0469(1980)037<2734:AMFTSA>2.0.CO;2

Westerling, A. L., Hidalgo, H. G., Cayan, D. R., \& Swetnam, T. W. (2006). Warming and earlier spring increase western U.S. forest wildfire activity. Science (New York, N.Y.), 313(5789), 940-943. http://doi.org/10.1126/science.1128834

Zasada, J. C., Norum, R. A., Teutsch, C. E., \& Densmore, R. (1987). Survival and growth of planted black spruce, alder, aspen and willow after fire on black spruce/feather moss sites in interior Alaska. Forestry Chronicle, 63(2), 84-88. 
Zasada, J. C., Norum, R. A., Veldhuizen, R. M. Van, \& Teutsch, C. E. (1983). Artificial regeneration of trees and tall shrubs in experimentally burned upland black spruce/feather moss stands in Alaska. Canadian Journal of Forest Research. http://doi.org/10.1139/x83120

Zhang, W., Miller, P. A, Smith, B., Wania, R., Koenigk, T., \& D?scher, R. (2013). Tundra shrubification and tree-line advance amplify arctic climate warming: results from an individual-based dynamic vegetation model. Environmental Research Letters, 8(3), 034023. http://doi.org/10.1088/1748-9326/8/3/034023

Zhang, Y. C., Rossow, W. B., Lacis, A. A., Oinas, V. and Mishchenko, M. I. (2004), Calculation of radiative fluxes from the surface to top of atmosphere based on ISCCP and other global data sets: Refinements of the radiative transfer model and the input data, Journal of Geophysical Research, 109, D19105, doi:10.1029/2003JD004457.

Zhu, Z., Wang, S., \& Woodcock, C. E. (2015). Improvement and expansion of the Fmask algorithm: cloud, cloud shadow, and snow detection for Landsats 4-7, 8, and Sentinel 2 images. Remote Sensing of Environment, 159, 269-277. http://doi.org/10.1016/j.rse.2014.12.014

Zhu, Z., \& Woodcock, C. E. (2012). Object-based cloud and cloud shadow detection in Landsat imagery. Remote Sensing of Environment, 118, 83-94. http://doi.org/10.1016/j.rse.2011.10.028 


\section{List of Figure Captions:}

Figure 1. The locations of the ten selected burn sites

Figure 2. Burn severity at the ten sites and Landsat-8 snow-free true color composite (red 0.00.1 , green $0.0-0.1$, blue $0.0-0.1$. The black line in site \#10 is the transect for the analysis of surface albedo and burn severity heterogeneity

Figure 3. 30m NLCD land types in 2011 at the ten sites

Figure 4. The locations of Morgan Monroe, Howland West, Table Mountain, Imnaviat, Barrow and Sioux Falls sites from Google map.

Figure 5. Landsat-7 blue sky shortwave albedo on DOY 201085 at scene p73r13 (A) and Landsat-8 blue sky shortwave albedo on DOY 2014088 at scene p73r13 (B). Bright blue areas indicate saturated signals

Figure 6. Comparison of Landsat-8 full expression blue-sky shortwave snow and snow-free albedo with ground albedo measurements.

Figure 7. Post-fire Landsat-8 (L8) OLI full expression shortwave blue sky albedo at the ten sites as well as the pre-fire Landsat 7 (L7) ETM+ full expression shortwave blue sky albedo on DOY 2010085 (Bright blue areas indicate saturated signals)

Figure 8. The minimum (A), maximum (B), mean (C) and standard deviation (D) of the 2014 Landsat-8 spring albedo within a 450m grid at site \#7 which was burned in 2004

Figure 9. The percentage of low (a), moderate (b) and high burn severity (c) within a 450m grid at site \#7 which was burned in 2004

Figure 10. Full expression shortwave blue sky pre-fire albedo on DOY 2009083, post-fire albedo on DOY 2014090 and burn severity transect at site \#10 (the black line in Figure 2) 
Figure 11. Time series of averaged pre-fire and post-fire shortwave full expression blue sky albedo for sites which were burned from 1984 to 2010.

\section{Figures:}

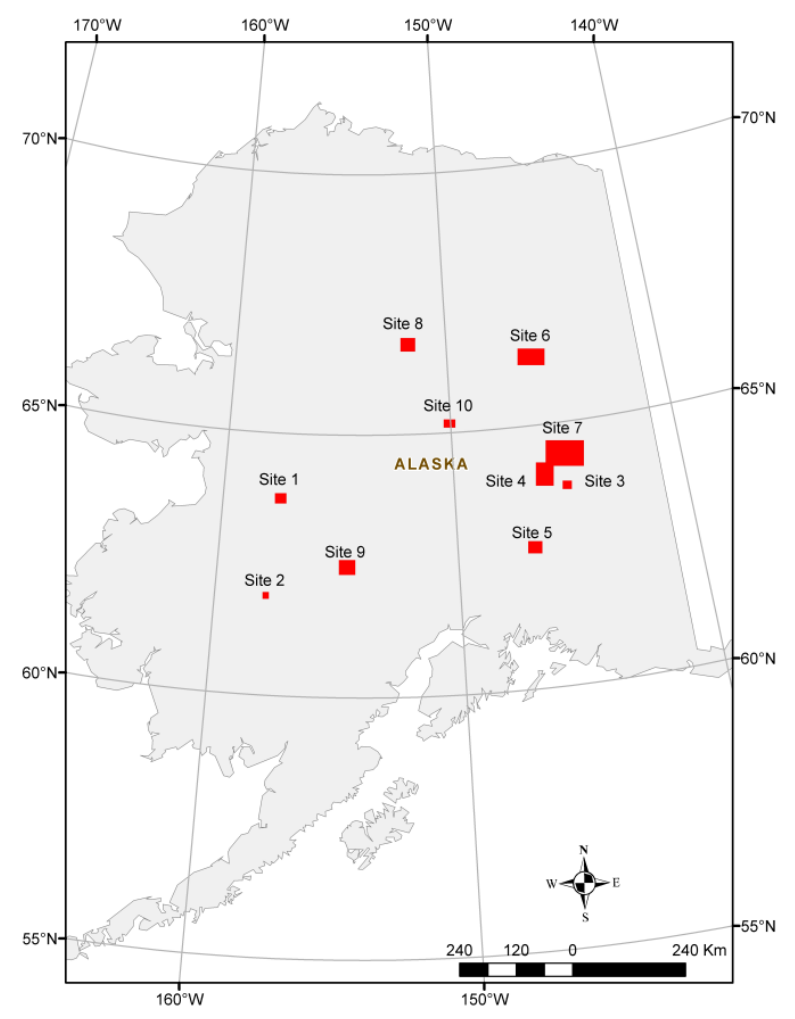

Figure 1. The locations of the ten selected burn sites 

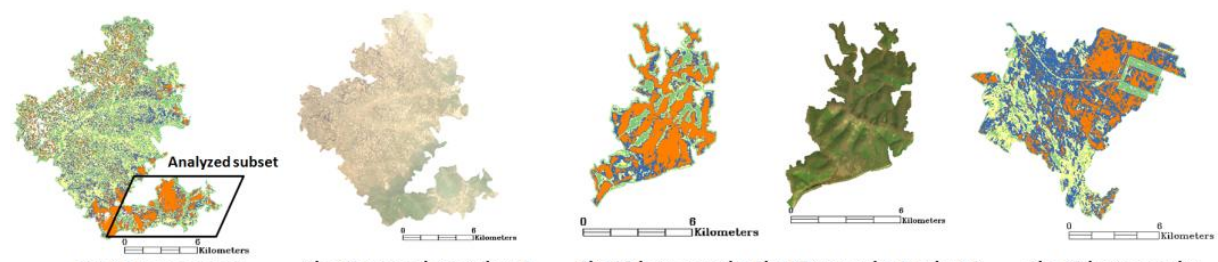

Site \#1 burn severity

Site \#1 true color Landsat-8

Site \#2 burn severity Site \#2 true color Landsat-8

Site \#3 burn severity

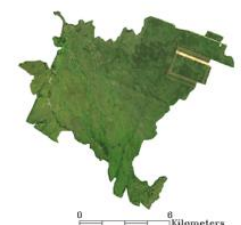

Site \#3 true color Landsat-8 on 2013194
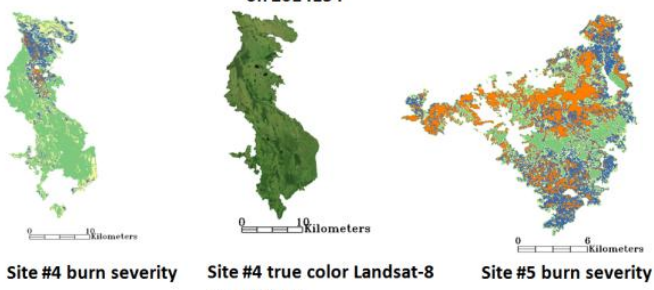
on 2014143

Site \#4 burn severity

Site \#4 true color Landsat-8 on 2013194

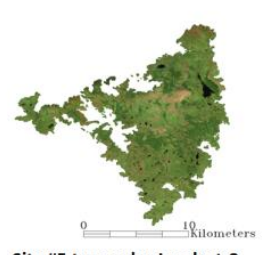

Site \#5 true color Landsat-8 on 2013219

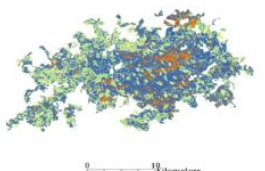

Site \#6 burn severity

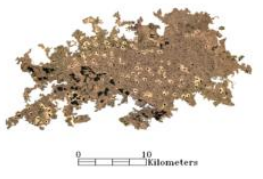

Site \#6 true color Landsat-8 on 2014140
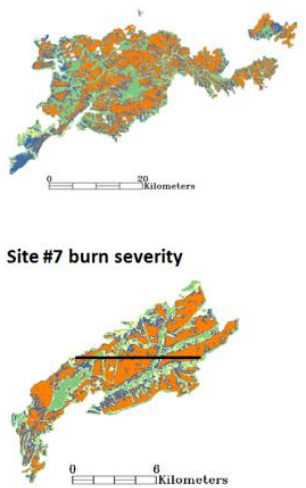

Site \#10 burn severity

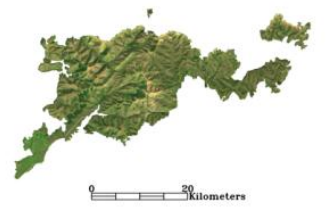

Site \#7 true color Landsat-8 on 2013194

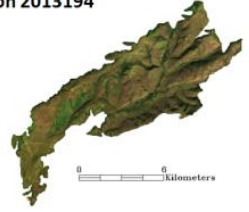

Site \#10 true color Landsat-8 on 2013238

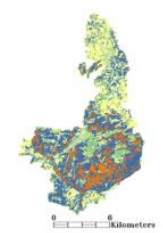

Site \#8 burn severity

$$
\begin{aligned}
& \text { Unburned to low severity } \\
& \text { Low severity } \\
& \text { Moderate severity }
\end{aligned}
$$$$
\text { Moderate severity }
$$$$
\text { High severity }
$$
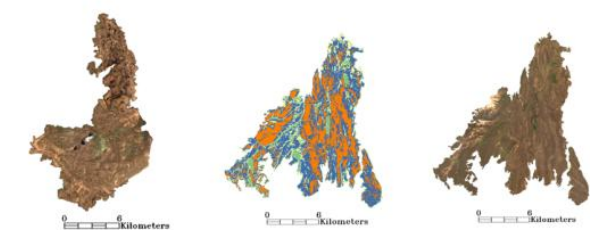

Site \#8 true color Landsat-8 Site \#9 burn severity Site \#9 true color Landsat-8 on 2014136 on 2013149

Figure 2. Burn severity at the ten sites and Landsat-8 snow-free true color composite (red 0.0-0.1, green $0.0-0.1$, blue $0.0-0.1$ ). The black line in site \#10 is the transect for the analysis of surface albedo and burn severity heterogeneity 


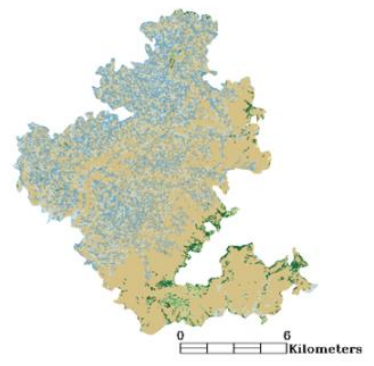

Site \#1

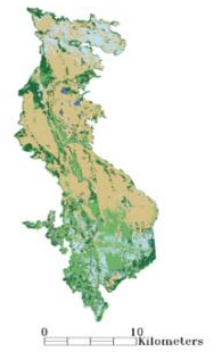

Site \#4

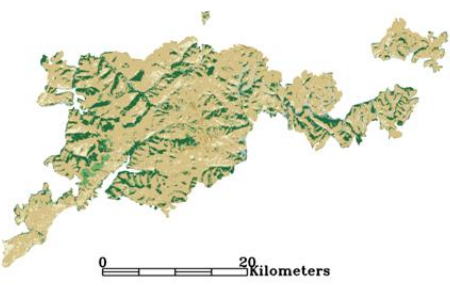

Site \#7

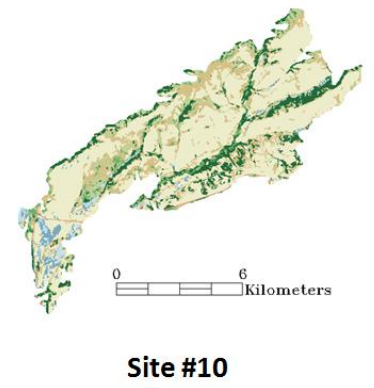

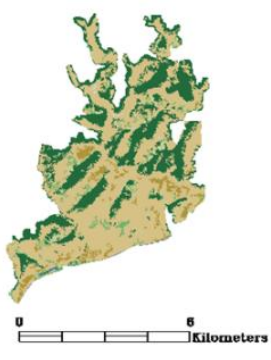

Site \#2

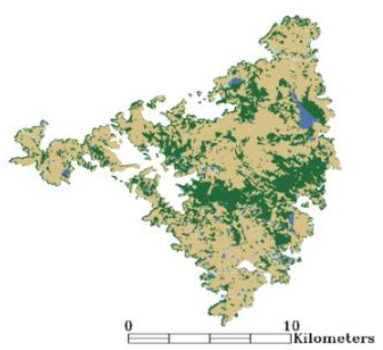

Site \#5

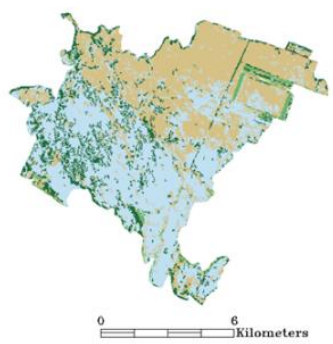

Site \#3

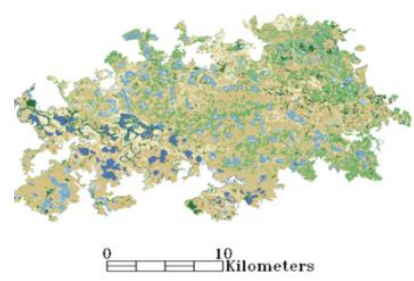

Site \#6

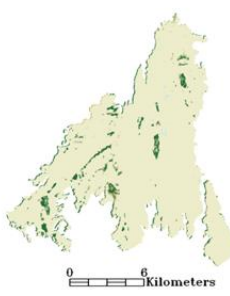

Site \#9

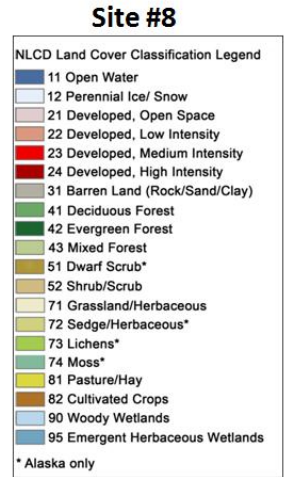

Figure 3. 30m NLCD land types in 2011 at the ten sites 

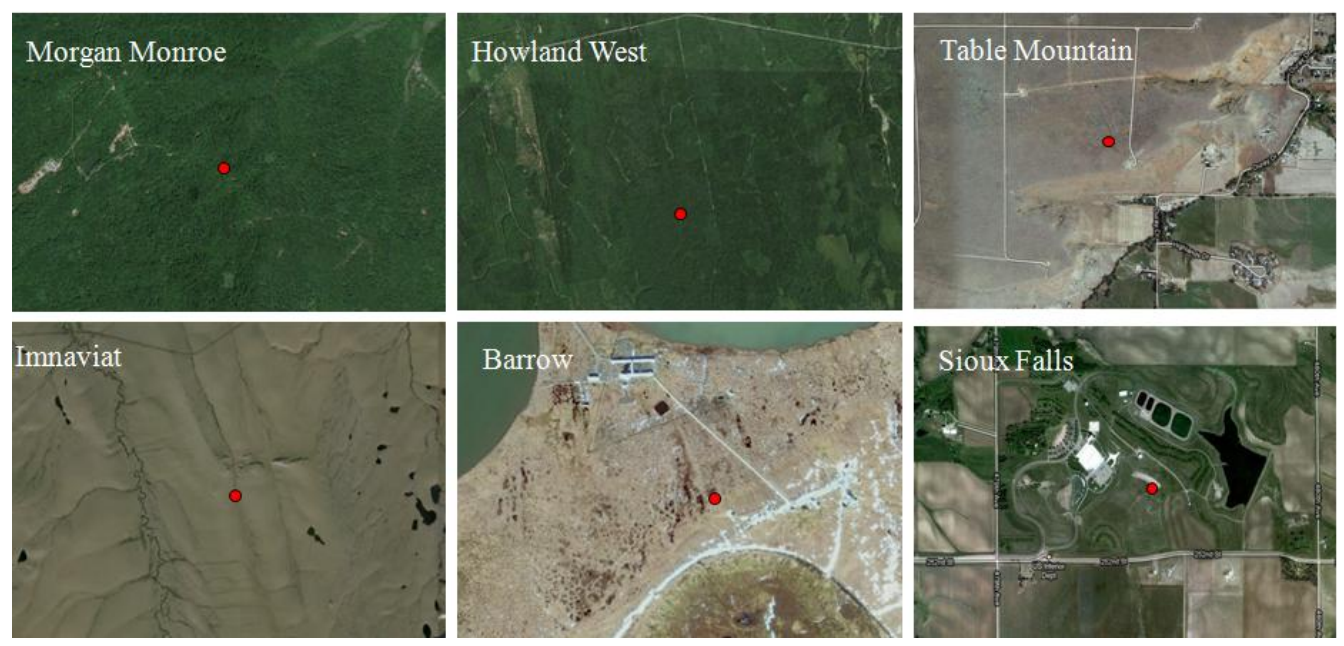

Figure 4. The locations of Morgan Monroe, Howland West, Table Mountain, Imnaviat, Barrow and Sioux Falls sites from Google map.

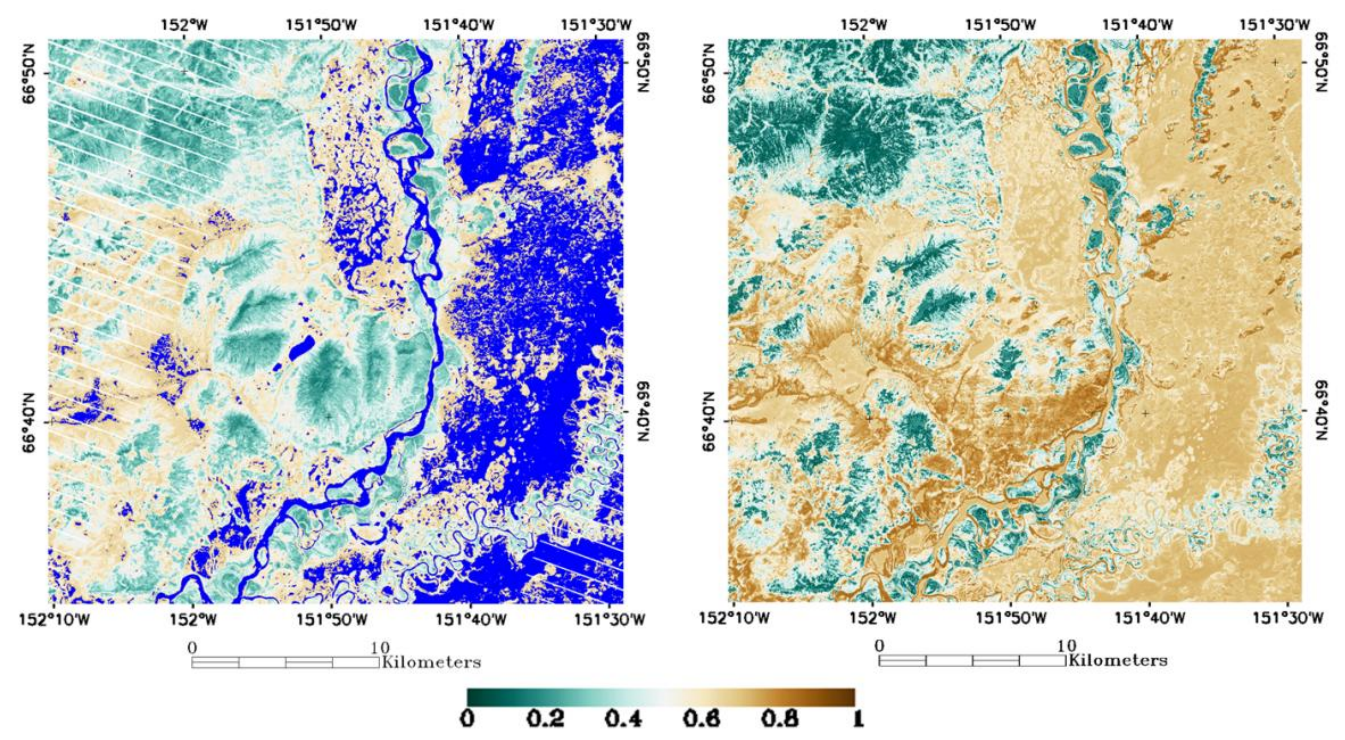

Figure 5. Landsat-7 blue sky shortwave albedo on DOY 201085 at scene p73r13 (A) and

Landsat-8 blue sky shortwave albedo on DOY 2014088 at scene p73r13 (B). Bright blue areas indicate saturated signals 

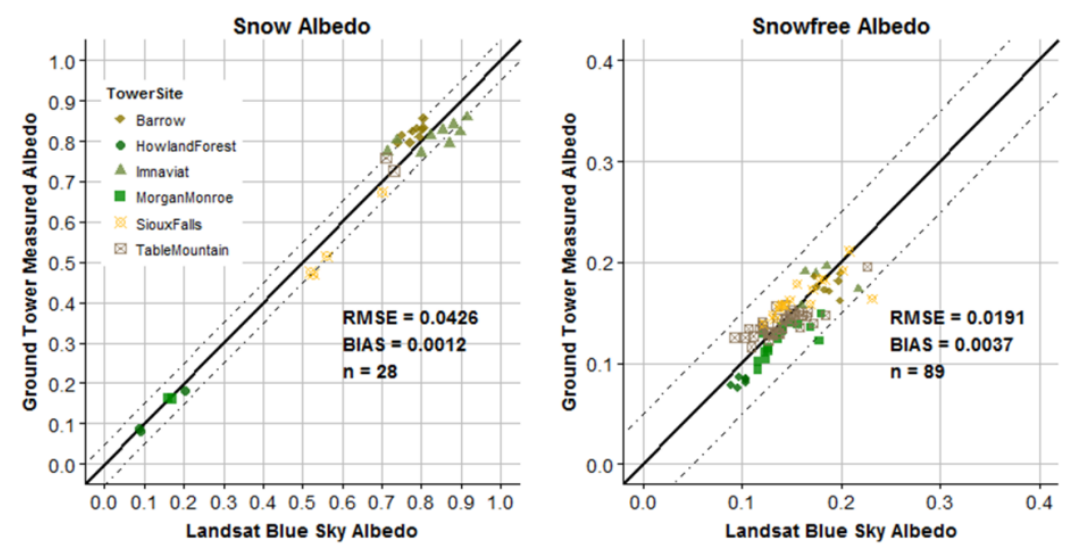

Figure 6. Comparison of Landsat- 8 full expression blue-sky shortwave snow and snow-free albedo with ground albedo measurements. 


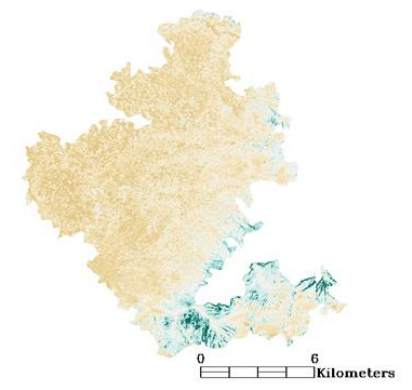

Site \#1 (L8)

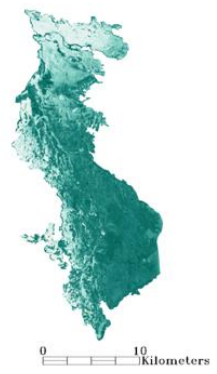

Site \#4 (L8)

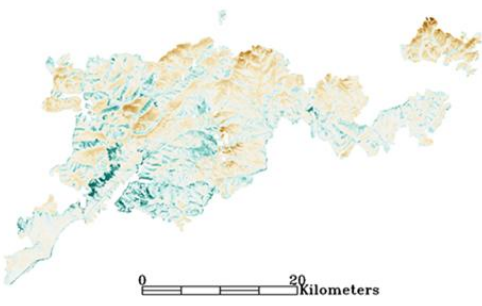

Site \#7 (L8)

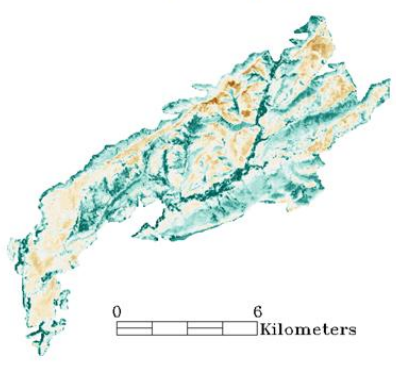

Site \#10 (L8)

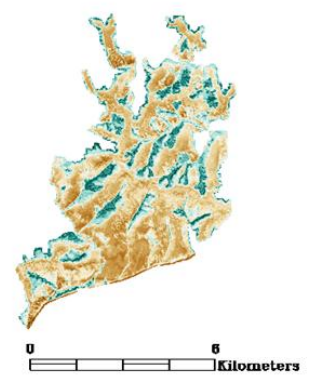

Site \#2 (L8)

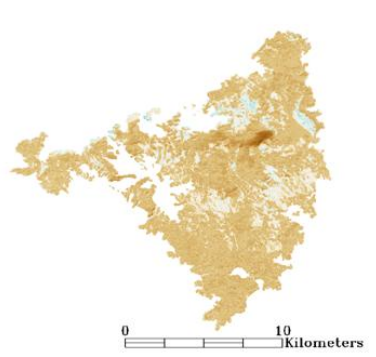

Site \#5 (L8)

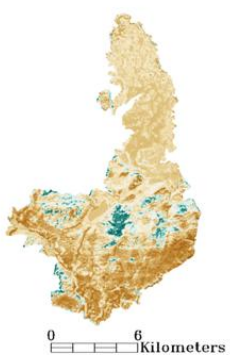

Site \#8 (L8)

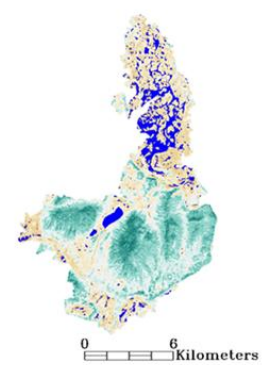

Site \#8 (L7) on 2010085

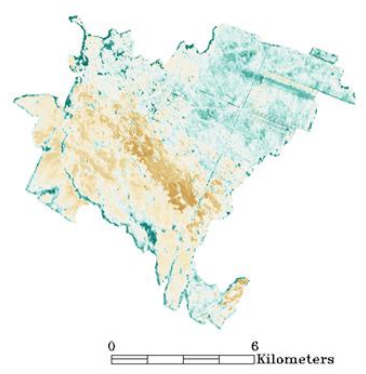

Site \#3 (L8)

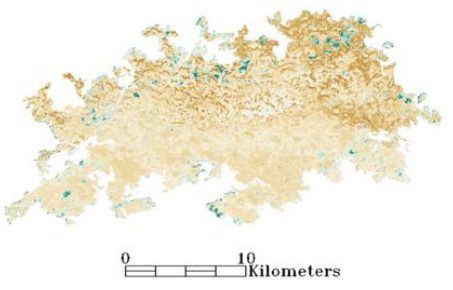

Site \#6 (L8)
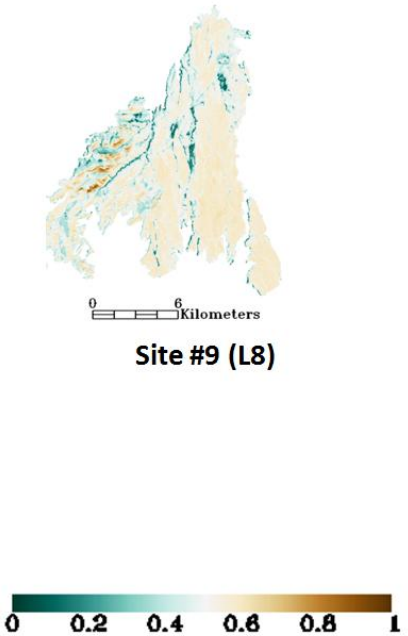

Figure 7. Post-fire Landsat-8 (L8) OLI full expression shortwave blue sky albedo at the ten sites as well as the pre-fire Landsat 7 (L7) ETM+ full expression shortwave blue sky albedo on DOY 2010085 (Bright blue areas indicate saturated signals) 

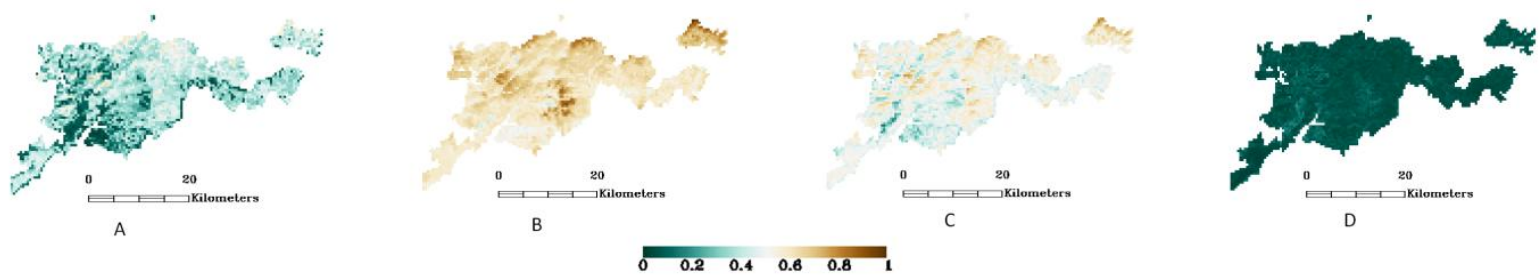

Figure 8. The minimum (A), maximum (B), mean (C) and standard deviation (D) of the 2014

Landsat-8 spring albedo within a 450m grid at site \#7 which was burned in 2004
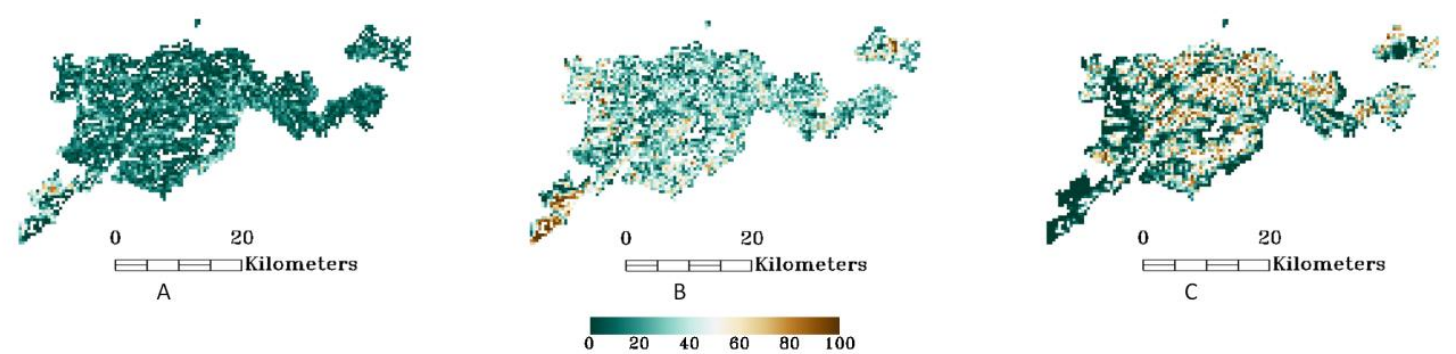

Figure 9. The percentage of low (a), moderate (b) and high burn severity (c) within a 450m grid at site \#7 which was burned in 2004

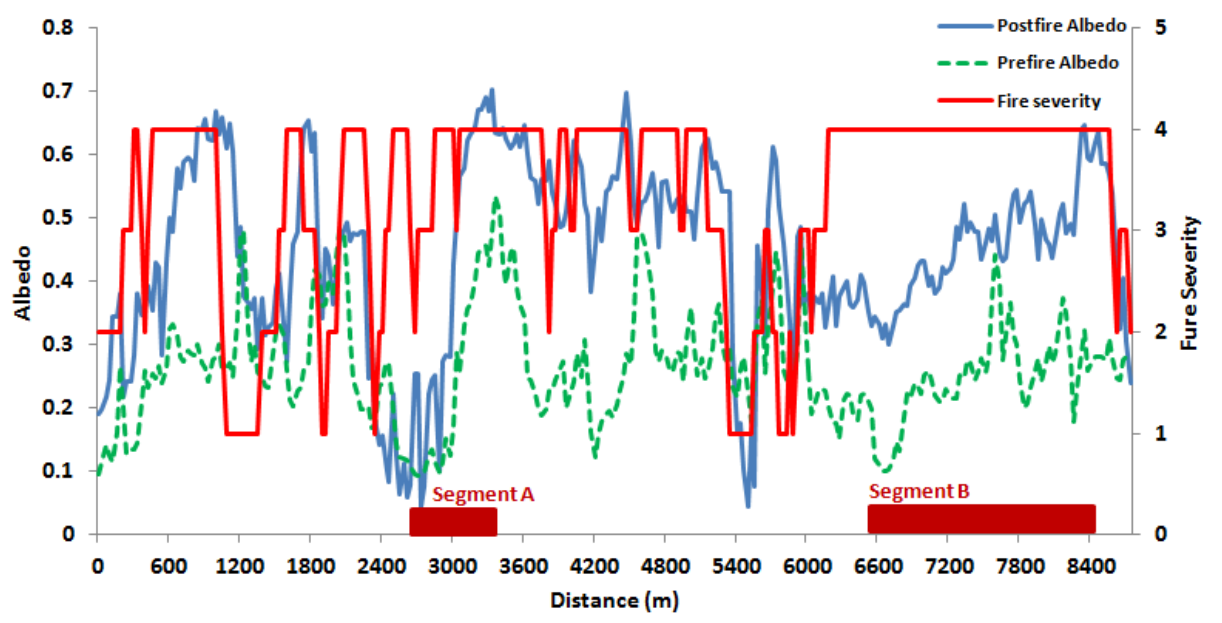

Figure 10. Full expression shortwave blue sky pre-fire albedo on DOY 2009083, post-fire albedo on DOY 2014090 and burn severity transect at site \#10 (the black line in Figure 2) 


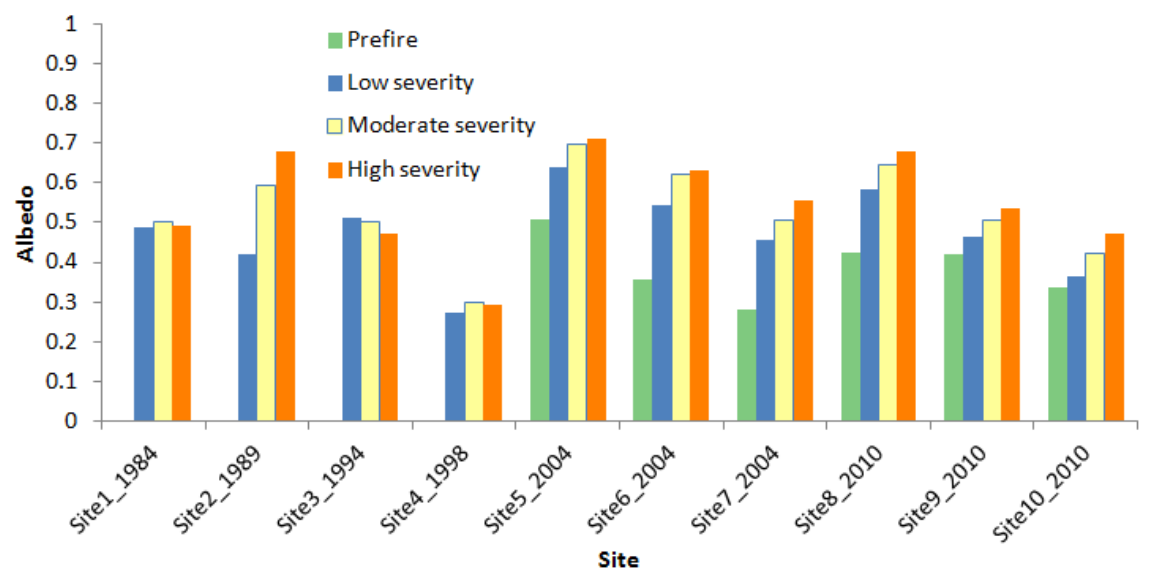

Figure 11. Time series of averaged pre-fire and post-fire shortwave full expression blue sky albedo for sites which were burned from 1984 to 2010 . 


\section{Tables:}

Table 1. Characteristics of boreal forest study areas

\begin{tabular}{|c|c|c|c|c|c|c|}
\hline $\begin{array}{l}\text { Site } \\
\text { name }\end{array}$ & $\begin{array}{l}\text { Year } \\
\text { burned }\end{array}$ & $\begin{array}{l}\text { Post-fire } \\
\text { Landsat data }\end{array}$ & $\begin{array}{l}\text { Pre-fire } \\
\text { Landsat data }\end{array}$ & $\begin{array}{l}\text { Landsat } \\
\text { scene }\end{array}$ & $\begin{array}{l}\text { Fire scar } \\
\text { size }\left(\mathrm{km}^{2}\right)\end{array}$ & $\begin{array}{l}\text { Land type (before } \\
\text { burned) }\end{array}$ \\
\hline Site \#1 & 1984 & $\mathrm{~L}^{8} / 2014086$ & N/A & p75r15 & $25.64 *$ & Evergreen forest \\
\hline Site \#2 & 1989 & L8/2014079 & N/A & p74r17 & 35.34 & Evergreen forest \\
\hline Site \#3 & 1994 & L8/2014062 & N/A & p67r15 & 86.41 & Evergreen forest \\
\hline Site \#4 & 1998 & L8/2014085 & N/A & p68r15 & 255.47 & $\begin{array}{l}\text { Deciduous, } \\
\text { evergreen forest }\end{array}$ \\
\hline Site \#5 & 2004 & L8/2014078 & L7/2002069 & p67r16 & 143.24 & Evergreen forest \\
\hline Site \#6 & 2004 & L8/2014092 & L7/2003070 & p69r13 & 363.64 & $\begin{array}{l}\text { Mixed forest, } \\
\text { evergreen forest, } \\
\text { deciduous forest }\end{array}$ \\
\hline Site \#7 & 2004 & L8/2014094 & L7/2002069 & p67r15 & 744.71 & Evergreen forest \\
\hline Site \#8 & 2010 & L8/2014088 & L7/2010085 & p73r13 & 125.40 & Evergreen forest \\
\hline Site \#9 & 2010 & L8/2014081 & L5/2009083 & p72r16 & 157.07 & $\begin{array}{l}\text { Dominated by } \\
\text { evergreen forest }\end{array}$ \\
\hline Site \#10 & 2010 & L8/2014090 & L7/2003068 & p71r14 & 75.38 & $\begin{array}{l}\text { Evergreen forest, } \\
\text { mixed forest }\end{array}$ \\
\hline
\end{tabular}

* Subset fire scar area used for this study (Figure 2)

${ }^{\S}$ L5 represents Landsat-5; L8 represents Landsat-8; L7 represents Landsat-7

Table 2. Characteristics of ground measurements for Landsat-8 albedo validation

\begin{tabular}{|c|c|c|c|c|c|c|c|}
\hline Name & Network & Latitude & Longitude & $\begin{array}{l}\text { Land } \\
\text { Cover }\end{array}$ & $\begin{array}{l}\text { Tower } \\
\text { Height/ } \\
\text { Footprint } \\
\text { Diameter } \\
\text { (m) }\end{array}$ & $\begin{array}{l}\text { Instrumen } \\
\text { tation }\end{array}$ & $\begin{array}{l}\text { Number of } \\
\text { Landsat-8 } \\
\text { images(sno } \\
\text { w/snow- } \\
\text { free) }\end{array}$ \\
\hline Barrow & BSRN & $71.323^{\circ} \mathrm{N}$ & $156.626^{\circ} \mathrm{W}$ & Tundra & $4 / 50.5$ & $\begin{array}{l}\text { Kipp and } \\
\text { Zonen } \\
\text { albedomete } \\
\text { rs }\end{array}$ & $8 / 7$ \\
\hline Imnavait & $\mathrm{AON}$ & $68.613^{\circ} \mathrm{N}$ & $149.312^{\circ} \mathrm{W}$ & $\begin{array}{l}\text { Tussock } \\
\text { Tundra }\end{array}$ & $2.5 / 30$ & $\begin{array}{l}\text { Eppley } \\
\text { Pyranomet } \\
\text { er }\end{array}$ & $9 / 5$ \\
\hline $\begin{array}{l}\text { Sioux } \\
\text { Falls }\end{array}$ & SURFRAD & $43.734^{\circ} \mathrm{N}$ & $96.623^{\circ} \mathrm{W}$ & Grassland & $10 / 127$ & $\begin{array}{l}\text { Eppley } \\
\text { Pyranomet } \\
\text { er }\end{array}$ & $4 / 17$ \\
\hline $\begin{array}{l}\text { Table } \\
\text { Mountain } \\
\text { (Boulder) }\end{array}$ & SURFRAD & $40.126^{\circ} \mathrm{N}$ & $105.238^{\circ} \mathrm{W}$ & Grassland & $10 / 127$ & $\begin{array}{l}\text { Eppley } \\
\text { Pyranomter }\end{array}$ & $2 / 38$ \\
\hline $\begin{array}{l}\text { Morgan } \\
\text { Monroe } \\
\text { State } \\
\text { Forest } \\
\text { Indiana } \\
\end{array}$ & Ameriflux & $39.323^{\circ} \mathrm{N}$ & $86.413^{\circ} \mathrm{W}$ & $\begin{array}{l}\text { Deciduous } \\
\text { Broadleaf } \\
\text { Forest }\end{array}$ & $48 / 610$ & $\begin{array}{l}\text { Kipp and } \\
\text { Zonen } \\
\text { albedomete } \\
\text { rs }\end{array}$ & $2 / 16$ \\
\hline $\begin{array}{l}\text { Howland } \\
\text { West } \\
\text { forest }\end{array}$ & Ameriflux & $45.209^{\circ} \mathrm{N}$ & $68.747^{\circ} \mathrm{W}$ & $\begin{array}{l}\text { Evergreen } \\
\text { Needlelea } \\
\text { f Forest }\end{array}$ & $30 / 366$ & $\begin{array}{l}\text { Kipp and } \\
\text { Zonen } \\
\text { albedomete } \\
\text { rs }\end{array}$ & $3 / 6$ \\
\hline
\end{tabular}


Table 3. Narrowband to broadband conversion coefficients for Landsat-8

\begin{tabular}{lccccccc}
\hline & Band2 & Band3 & Band4 & Band5 & Band6 & Band7 & Constant \\
\hline Snow free VIS & 0.5621 & 0.1479 & 0.2512 & & & & -0.0015 \\
Snow free NIR & & & & 0.5911 & 0.3155 & 0.0731 & 0.0019 \\
Snow free SW & 0.2453 & 0.0508 & 0.1804 & 0.3081 & 0.1332 & 0.0521 & 0.0011 \\
$\quad$ Snow VIS & 0.7536 & 0.3244 & -0.0780 & & & & -0.0063 \\
Snow NIR & & & & 0.6034 & 0.0039 & 0.8897 & -0.0198 \\
$\quad$ Snow SW & 1.2242 & -0.4318 & -0.3446 & 0.3367 & 0.1834 & 0.2555 & -0.0052 \\
\hline
\end{tabular}

Table 4. RMSE and bias of the full expression blue sky albedo at Landsat- 8 validation sites

\begin{tabular}{|c|c|c|c|c|c|c|}
\hline Land Cover & \multicolumn{2}{|c|}{ Forest $\left(n^{*}=27\right)$} & \multicolumn{2}{|c|}{ Tundra/Grass $(n=90)$} & \multicolumn{2}{|c|}{ All $(n=117)$} \\
\hline Season & Snow & Snow-Free & Snow & Snow-Free & Snow & Snow-Free \\
\hline RMSE & 0.0114 & 0.0207 & 0.0467 & 0.0185 & 0.0426 & 0.0191 \\
\hline BIAS & 0.0074 & 0.0168 & -0.0001 & -0.0006 & -0.0013 & 0.0037 \\
\hline
\end{tabular}

*Number of Landsat-8 images for validation

Table 5. Characteristics of shortwave full expression blue sky albedo and burn severity over different forest types at site \#6 and site \#9

\begin{tabular}{|c|c|c|c|c|c|c|c|c|}
\hline $\begin{array}{l}\text { Site } \\
\text { name }\end{array}$ & $\begin{array}{l}\text { Pre-fire } \\
\text { land type }\end{array}$ & $\begin{array}{c}\text { Pre- } \\
\text { fire } \\
\text { albedo }\end{array}$ & $\begin{array}{l}\text { Mean } \\
\text { albedo } \\
\text { for low } \\
\text { burn } \\
\text { severity }\end{array}$ & $\begin{array}{l}\text { Percentage } \\
\text { of low burn } \\
\text { severity } \\
\text { pixels } \\
(100 \%)\end{array}$ & $\begin{array}{l}\text { Mean } \\
\text { albedo for } \\
\text { moderate } \\
\text { burn } \\
\text { severity }\end{array}$ & $\begin{array}{l}\text { Percentage } \\
\text { of } \\
\text { moderate } \\
\text { burn } \\
\text { severity } \\
\text { pixels } \\
(100 \%) \\
\end{array}$ & $\begin{array}{l}\text { Mean } \\
\text { albedo } \\
\text { for high } \\
\text { burn } \\
\text { severity }\end{array}$ & $\begin{array}{l}\text { Percentage } \\
\text { of high } \\
\text { burn } \\
\text { severity } \\
\text { pixels } \\
(100 \%) \\
\end{array}$ \\
\hline \multirow{3}{*}{$\begin{array}{l}\text { Site } \\
\# 6\end{array}$} & $\begin{array}{l}\text { Evergreen } \\
\text { forest }\end{array}$ & 0.32 & 0.56 & 34.06 & 0.63 & 56.14 & 0.62 & 9.81 \\
\hline & $\begin{array}{l}\text { Deciduous } \\
\text { forest }\end{array}$ & 0.38 & 0.53 & 19.69 & 0.61 & 70.58 & 0.64 & 9.73 \\
\hline & $\begin{array}{l}\text { Mixed } \\
\text { forest }\end{array}$ & 0.33 & 0.52 & 26.01 & 0.62 & 63.51 & 0.62 & 10.48 \\
\hline \multirow{2}{*}{$\begin{array}{l}\text { Site } \\
\# 9\end{array}$} & $\begin{array}{l}\text { Evergreen } \\
\text { forest }\end{array}$ & 0.39 & 0.45 & 12.99 & 0.50 & 50.38 & 0.53 & 36.63 \\
\hline & $\begin{array}{l}\text { Mixed } \\
\text { forest }\end{array}$ & 0.45 & 0.50 & 18.75 & 0.53 & 47.16 & 0.57 & 34.08 \\
\hline
\end{tabular}

